\title{
The Geochemistry and Geochronology of the Quaternary Volcanism of the Kassa Volcanic Field (KVF), Jos Plateau, North Central Nigeria
}

\author{
Mohammed S. Tsalha ${ }^{1}$, U. A. Lar ${ }^{2}$,T.A Yakubu ${ }^{1}$, Jon Blundy ${ }^{3}$, and H.W Bart ${ }^{4}$ \\ ${ }^{1}$ Centre for Geodesy and Geodynamics, Toro, National Space Research and Development Agency (NASRDA), \\ Nigeria.tsalhamohammed@yahoo.com, GSM: +2348036381065 \\ 2 Geology and Mining Department, University of Jos, Plateau State, Nigeria \\ ${ }^{3}$ School of Earth Sciences, University of Bristol, United Kingdom \\ ${ }^{4}$ Geological Survey of Norway, Trondheim, Norway
}

\begin{abstract}
Thirty lava flows of alkaline olivine volcanic rocks of Quaternary age occurrence in the Kassa Volcanic Field (KVF), north central, Nigeria. Basalts contain phenocrysts of olivine, clinopyroxene, Fe-Ti oxides (magnetite and/or ilmenite) and abundant microlites of plagioclase forming the groundmass. There is a large compositional gap between basaltic rocks and felsic lavas discovered in the study area. Despite this gap, major-and trace-element distributions are in favour of a co-magmatic origin for the basaltic lavas in this area. The Kassa Volcanic Field (KVF) basalts are similar in their chemical features to the basalts from other parts of the Jos, Biu Plateaux and Cameroun Volcanic Line (CVL). It is believed that the KVF basaltic magmas originate from an intra-lithospheric homogeneity reservoir. The previous isotopic studies suggested that they are related to mantle-derived magmas and they are resulted from the mixing at shallow crustal levels of a large fraction of basaltic magma with a minor amount of trachytic magma. Major element modelling of the basalttrachyte evolution supports an evolution through fractional crystallization. The fluids have played a significant role in the mafic lavas genesis, as attested by the occurrence of Fe-rich minerals. An origin of the Kassa volcanic magmas by fractional crystallization of mantle-derived primitive magmas of basaltic composition, accompanied by volatile, halogen-rich fluid phases, may probably be the preferred hypothesis for the genesis of these lavas. The striking feature of the analytical results from the radiometric dating is an age convergence around $1.3 \mathrm{Ma}$. One sample from cone three (CN3) give slightly different value of 2.5Ma despite this, it cannot be considered to be significantly different and the samples from this cone presents more olivine and clinopyroxene phenocrysts. The assumed instantaneous cooling of the rocks, the freshness of the samples and the aforementioned age convergence lead us to regard the 1.3Ma age as mirroring the emplacement of the volcanic rocks. Moreover, the age range suggests a rather partial progression that decreases from the northern extremity to the southern portion of KVF (1.97 Ma-1.66 Ma-1.38 Ma and 1.34 Ma).
\end{abstract}

Keywords: Geochronology, Petrology, Quaternary volcanism, Kassa Volcanic Field, Ar-Ar dating, Jos Plateau.

\section{Introduction}

The Jos Plateau lies precisely within the North Central Basement Complex of Nigeria. The basement Complex rocks of the lower Palaeozoic to Precambrian ages underlie about half of its entire landmass (Fig.1) These rocks are represented by gneiss-migmatites and intrusive into these Basement rocks are the Pan-African granites and the predominant Jurassic non-orogenic alkaline Younger Granites (Turner, 1976). 


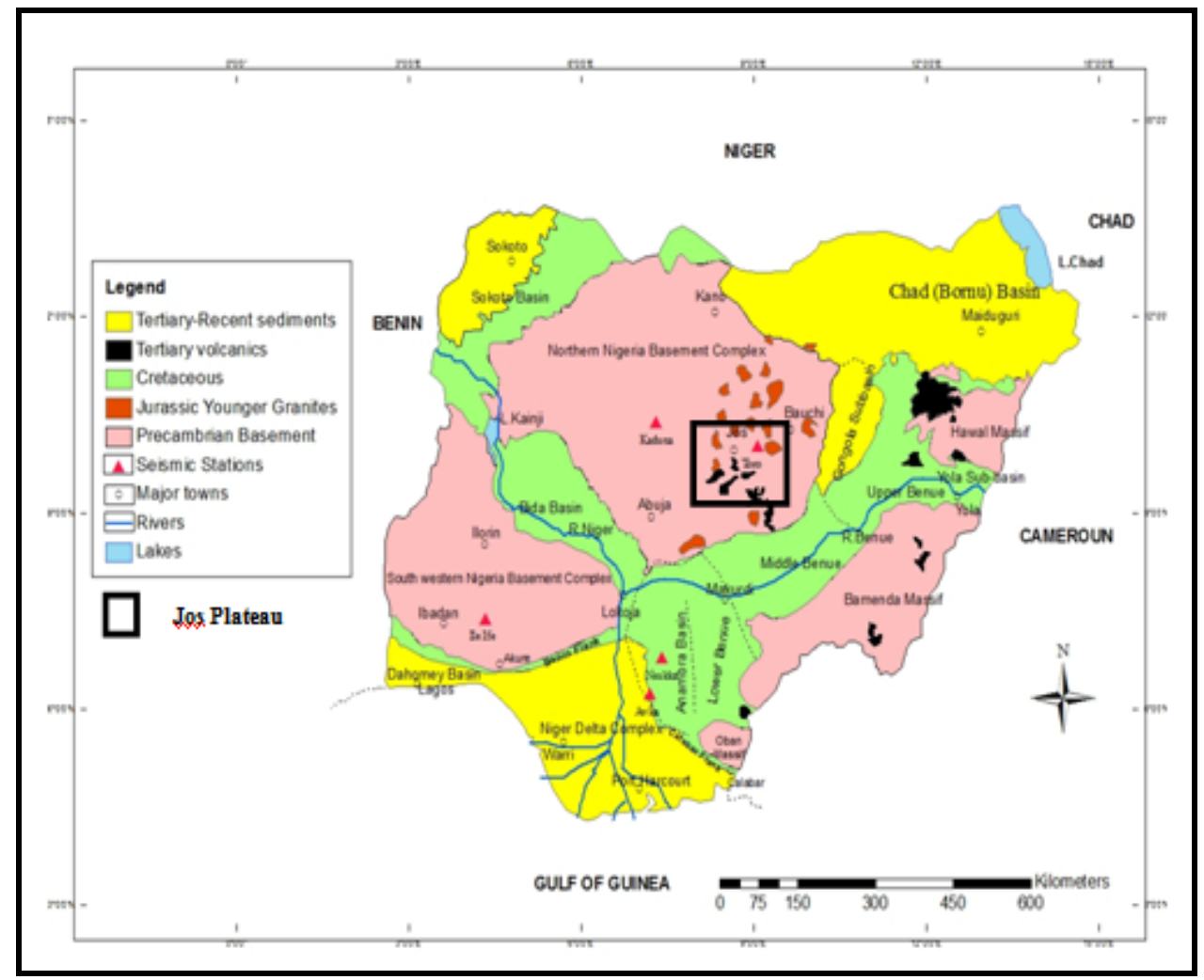

Fig 1: The Geologic map of Nigeria showing Jos Plateau (Modified after Akpan and Yakubu, 2010)

Tertiary and Quaternary basaltic volcanoes are the youngest rocks in the area and overlie directly on the basement and in some places on the Younger Granites (Wright, 1970). Two main basaltic subtypes have been distinguished based on their periods of replacement and textural differences. They are the Older (Tertiary) and the Newer (Quaternary) basalts (MacLeod et al., 1971, Lar and Tsalha., 2004). The Newer Basalts occupy nearly $150 \mathrm{~km}^{2}$ in the western and southern Jos Plateau. They also extend towards the Kafanchan area and Southwards down to the Shemankar valley. They occur as cones and lava flow characterised steep-sided central craters rising a few meters above their surroundings. The Newer Basaltic cones are aligned in NNW-SSE direction, corresponding to the trend of dolerite dykes (MacLeod et al., 1971). They are mainly built of basaltic scoria and pyroclastics materials. The petrography of the Jos Plateau basalts has relatively been studied in detail (Carter et al., 1963; Wright, 1976). But geochemical data on these basalts however remain very scanty. Petrographically, the two main basalt sub-units (Newer/Older) exhibit similar mineralogical compositions consisting of olivine, pyroxene (augite-titanaugite), clinopyroxene, plagioclase (labradorite), opaque minerals (mostly ilmenite and/or magnetite) and a few quartz as accessory minerals. The Newer Basalts however present higher percentage of olivine. Texturally however, these two sub-types are different. The Newer Basalts are mainly vesicular, riddled with small cavities attributed to escaping gases and water vapour. The vesicles are sometimes filled with minerals like olivine, garnet etc. The Older Basalts are mainly porphyritic, where large phenocrysts of one or more of the major mineral constituents is/are set in a finely crystalline groundmass.

The striking feature of the analytical results (Table 1) is an age convergence around 1.3 Ma. One sample from cone $(\mathrm{CN} 3)$ give slightly different value of $2.5 \mathrm{Ma}$ despite this cannot be considered to be significantly different. The assumed instantaneous cooling of the rocks, the freshness of the samples and the aforementioned age convergence lead us to regard the 1.3 Ma age as mirroring the emplacement of the volcanic rocks. Moreover, the age range suggests a rather partial progression that decreases from the northern extremity to the southern portion of KVF (1.97Ma-1.66Ma- 1.38Ma and 1.34Ma). An earlier study of the lava flows from the KVF by Grant et al., 1972, reported the ages of 0.9Ma and 2.1Ma.

\section{Geological Setting}

The entire Heipang - Kassa area is dominated by the volcanic rocks (lava flow) which are underlay by Precambrian Basement rocks (Migmatites and Gneisses). The Precambrian Basement rocks are pre-existing rocks that were exposed at the surface due to weathering and denudation activities. In some places, they have been intruded by a series of Late Precambrian to lower Paleozoic (So-called Pan African Granite).

The next major geological event in the area was the emplacement of the Younger Granites of Jurassic age (160 million years ago). Although this geological event does not have any representation in the physical geological 
aspects of the area of study, it is worth mentioning, as it helps complete the pictures of the major geological events in the area and also because of its importance especially in tin mineralization. For instance, after the intrusion of the Younger Granites uplift, tectonic movements at a rate of millimetre per year developed denudation which slowly and consequently since about 200 million years lowered the original surface by several kilometers (Ajakpe and Okonkwo 1986). Another major geological event in the study area is the deposition of Cenozoic volcanism of alkaline affinity, which affected the Jos - Plateau generally (Hossain et al., 1986). Of directed relevance to the project is the deposition of two periods of volcanism in this area (Ajakpe and Okonkwo,1986, Dessanvagie and Whiteman,1970), they are the Older Basalt of Mid - Tertiary (about 32 Ma ago) and the Newer Basalt of Quaternary times (Hossain et al., 1986). And the most recent one the work of Lar and Tsalha, 2004 which grouped the basalts into Newer and Older basalts based on their geochemical and petrological characteristics.

The lava and intrusive exposures have been carefully sampled during intensive fieldwork with the help of native inhabitants. A 1/50,000-scale geological map has been established (Fig. 2). Eight volcanic cones and basaltic lava flows are scattered in this area were encountered. The heights of the cones vary between 50 and $350 \mathrm{~m}$, the smallest cone being only $50 \mathrm{~m}$ high. They are generally broadly circular (diameter between 300 and $700 \mathrm{~km}$ ) and sometimes elongated (1-1.2 km).

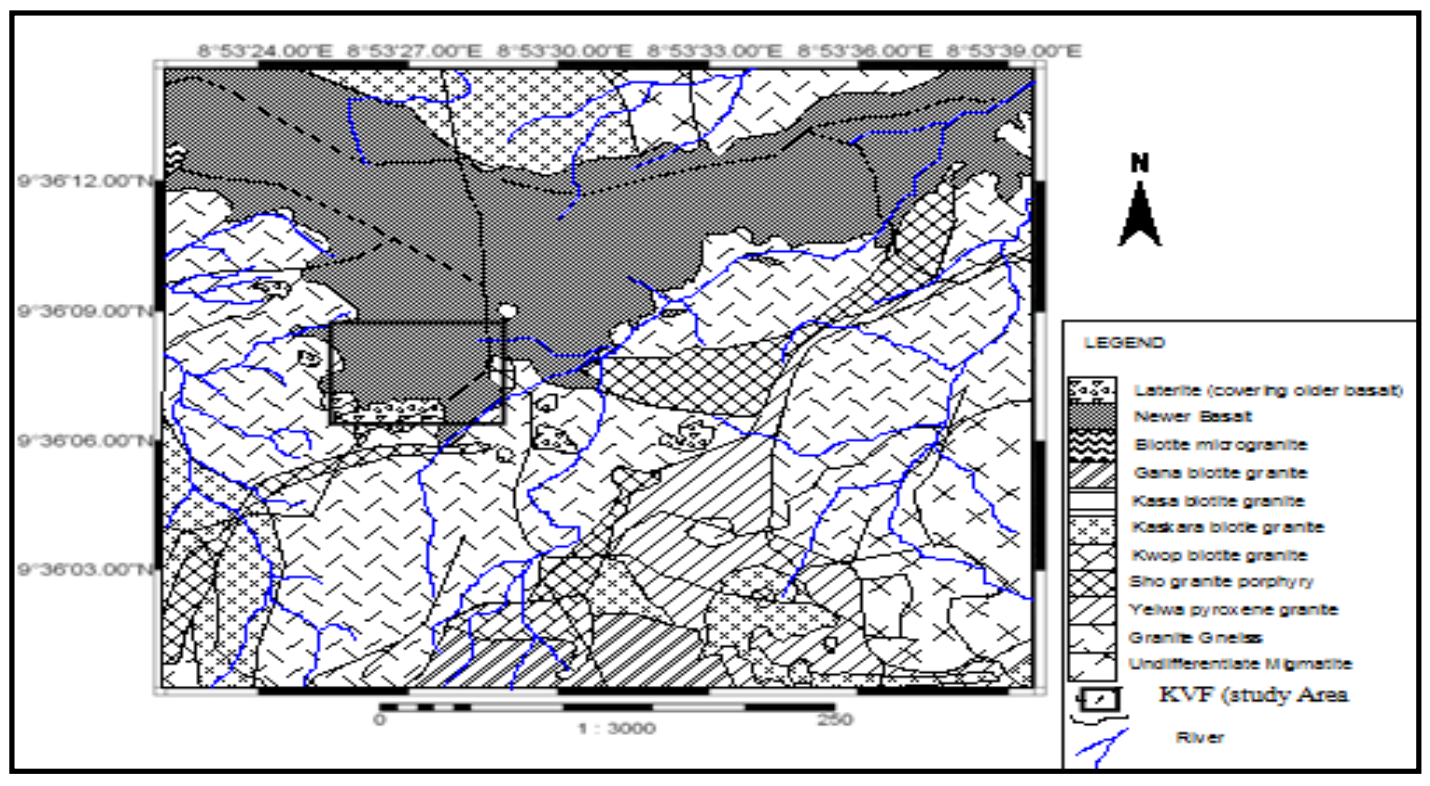

Fig.2: The Geologic Map of the Kassa Volcanic Field (KVF)

\section{Ar-Ar Dating}

The eight basaltic rock samples collected from the different volcanic cones from the KVF were shipped to Norway Geological Survey laboratory for analytical measurements using ${ }^{40} \mathrm{Ar}-{ }^{39} \mathrm{Ar}$ step-wise heating method. The analytical protocol was carried out with a lot of cautions to avoid serious errors and therefore, careful procedures were followed to obtain good results. The analytical data are presented in Table 1.

All the basaltic rock samples were crushed, sieved and washed in acetone and distilled water. The transformation ${ }^{38} \mathrm{~K}(\mathrm{n}, \mathrm{p}){ }^{39} \mathrm{Ar}$ was performed during irradiation at the IFE Kjeller nuclear reactor in Norway, using Taylor Creek Rhyolite (28.619 $\pm 0.034 \mathrm{Ma}$, Renne et al., 2010). The samples were step heated in the ${ }^{40} \mathrm{Ar} /{ }^{39} \mathrm{Ar}$ laboratory at the Geological Survey of Norway using a Merchantek MIR-10 $\mathrm{CO}_{2}$ laser. The extracted gases were swiped over getters (SAES AP-10) for 2 minutes, and then for 9 minutes in a separate part of the extraction line. The peaks were determined by peak hopping (at least 8 cycles) on masses ${ }^{41} \mathrm{Ar}$ to ${ }^{35} \mathrm{Ar}$ on a blazer electron multiplier on a MAP 215-50 mass spectrometer. Data from unknowns were corrected for blanks (every $4^{\text {th }}$ analysis is blank) prior to being reduced with the Interactive Ar-Ar Analysis (IAAA) software package (written by M. Generod, NGU Trondheim, Norway) that implemented the equations in McDougall and Harrison., (1999) using the decay constants of Renne et. al.,(2012) and the trapped ${ }^{40} \mathrm{Ar} /{ }^{36} \mathrm{Ar}$ ratio of $298.56 \pm$ 0.31 of Lee et al., (2006). Data reduction in IAAA incorporates corrections for interfering isotopes (based on $\mathrm{K}_{2} \mathrm{SO}_{4}$ and $\mathrm{CaF}_{2}$ salts included in the irradiation package) mass discrimination, error in blanks and decay of ${ }^{37} \mathrm{Ar}$ and ${ }^{39} \mathrm{Ar}$. Atomic constants suggested by Steiger and Jager., (1977) were used for calculating the ages. All analytical errors represent one standard deviation (i.e 68\% analytical confidence level).

The striking feature of the analytical results (Table 1) is an age convergence around 1.3 Ma. One sample from cone (CN3) give slightly different value of $2.5 \mathrm{Ma}$ despite this cannot be considered to be significantly different. 
The assumed instantaneous cooling of the rocks, the freshness of the samples and the aforementioned age convergence lead us to regard the 1.3 Ma age as mirroring the emplacement of the volcanic rocks. Moreover, the age range suggests a rather partial progression that decreases from the northern extremity to the southern portion of KVF (1.97Ma-1.66Ma- $1.38 \mathrm{Ma}$ and $1.34 \mathrm{Ma})$. The petrographic study revealed that the magma is homogeneous melts and probably from the source between 1.3 and 2.5 Ma. The lavas are named (Fig. 3) according to both the Differentiation Index (D.I., Thornton and Tuttle 1960) and phenocryst distribution (Fig. 4, Table 2). The lava in $\mathrm{KVF}$ is basalts $(\mathrm{CN} 1-\mathrm{CN} 8)$ have a porphyritic texture with phenocrysts of olivine ( 0.6 to $2 \mathrm{~mm}$ ), brown clinopyroxene (no green cores have been observed), $\mathrm{Fe}-\mathrm{Ti}$ oxides and rare plagioclase. The groundmass is fine grained with an intergranular texture, and composed of plagioclase, subhedral to anhedral brown clinopyroxene and Fe-Ti oxides. Almost all basalts contain phenocrysts of olivine and are embayed and rimmed by brown Fe-Ti oxides ( ilmanite). The biotite granite (sample KSS 39) contains abundant plagioclase (with pink core and brownish rim) and of Fe-Ti oxides. They are distinct from basaltic lavas as they do not contain any of the phenocrysts present in the other lavas analyzed from KVF. They contain K-feldspar (replaced by analcite), apatite, and unstable biotite more or less transformed into Fe-Ti oxides. In this samples some minerals identified includes: Tin, tungsten, fluoride and zirconium.

Table 1: Results of Kassa Basaltic Rocks Using Argon/Argon Dating Method: Sample -By - Sample Description of Results

\begin{tabular}{|l|l|l|l|l|l|l|}
\hline S/N & $\begin{array}{l}\text { Sample } \\
\text { Code/Coordinate }\end{array}$ & $\begin{array}{l}\text { Altitude } \\
(\mathbf{m})\end{array}$ & $\begin{array}{l}\text { Age Dated } \\
\text { (Million) }\end{array}$ & MSWD & 6 (Sigma) & Remarks \\
\hline 1 & $\begin{array}{l}\text { CN 3 (Cone 3) } \\
\text { N09 36.082 } \\
\text { E853.648 } \\
\text { CN 5 (Cone 5) } \\
\text { N0936.132 } \\
\text { E853 398 }\end{array}$ & 1314 & $2.5 \pm 0.318 \mathrm{Ma}$ & 1.318 & 26 & A good spectrum \\
3 & $\begin{array}{l}\text { CN 6 (Cone 6) N09 36 } \\
442 \\
\text { E853 195 }\end{array}$ & 1325 & $1.38 \pm 0.538 \mathrm{Ma}$ & $\begin{array}{l}\text { Too High } \\
(1.388)\end{array}$ & 26 & Good Spectrum \\
\hline $\begin{array}{l}\text { CN 7 (Cone 7) } \\
\text { N09 36.073 } \\
\text { E853.541 } \\
\text { CN 8 (Cone 8) } \\
\text { N09 36.138 } \\
\text { E853.570 }\end{array}$ & 1347 & $1.661 \pm 0.195 \mathrm{Ma}$ & $\begin{array}{l}\text { Too High } \\
(1.661)\end{array}$ & 26 & Good Spectrum \\
\hline
\end{tabular}

Among the eight volcanic cones mapped out, the basaltic samples collected from the northern extremity of the Kassa Volcanic Field (KVF) revealed that sample CN3 (cone 3) is the oldest volcanic structure of the study area. The oldest volcanic eruption episode was dated at about 2.5Ma ago. Four samples were dated ranges from 1.34 -1.97 Ma (CN5 -1.97 Ma CN7-1.66 Ma CN6-1.38 Ma and CN8-1.34Ma) the concordance of the dates above is convincing evidence of the reality volcanic activity of these age

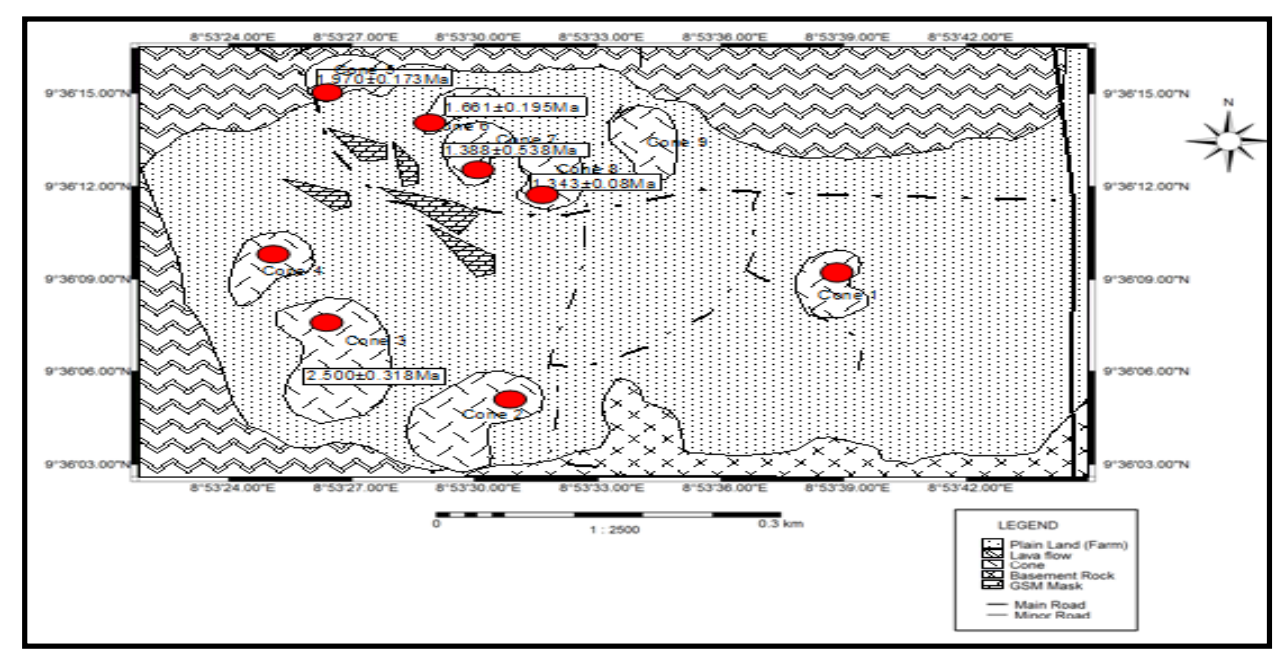

Fig.3: The Geologic Map of the Kassa Volcanic Field showing the Volcanic Cones as Samples collection Points 


\section{Results}

The latest episode dated volcanic occurrence of KVF corresponds to the volcanic cones is the sample CN8 (cone 8) which dated $1.34 \pm 0.080 \mathrm{Ma}$. The MSWD is 0.673 , on the samples taken from the same stratigraphic position yield ages that they are reproducible and indistinguishable from one another. Probably the best approach of the time of eruption can be given by mean age $1.35 \mathrm{Ma}$. The youngest $\mathrm{Ar} / \mathrm{Ar}$ age (1.34Ma) obtained from sample CN8 (cone 8) which was collected from the southern part of Kassa Volcanic Field (KVF), this reflects the latest volcanic activity of KVF.

The petrographic studies revealed that the young basaltic lava flow contains olivine phenocrysts and clinopyroxene with some associated opaque minerals. While the older cones do not contains these minerals in abundance, probably due to weathering and some denudation activities that occurred in this area.

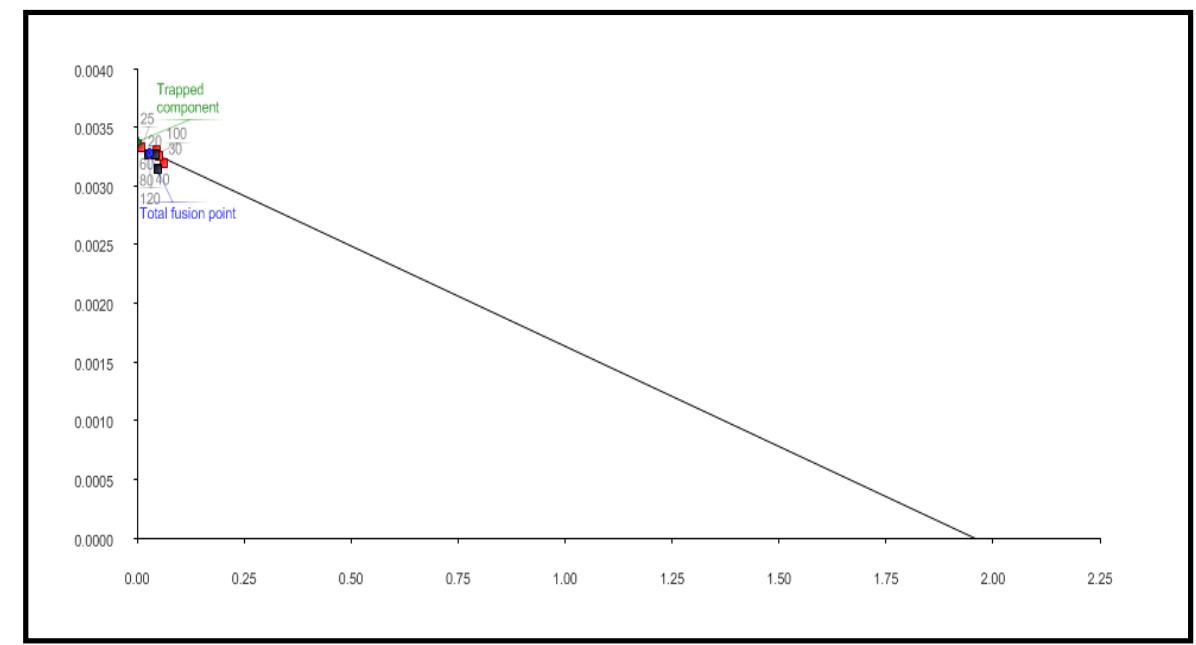

Fig. 4a: The Inverse Isochron of the Sample collected from Cone 6 at Kassa Volcanic Field

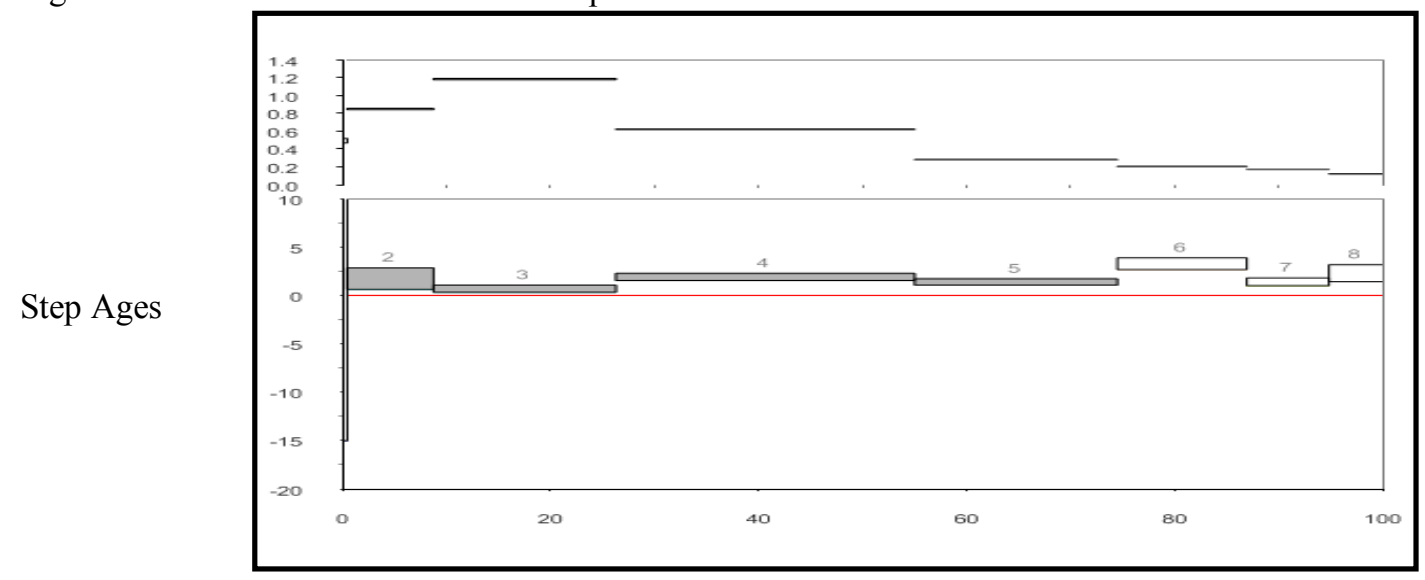

Fig 4b: The Age Spectrum of the Sample collected from Cone 6 at Kassa Volcanic Field

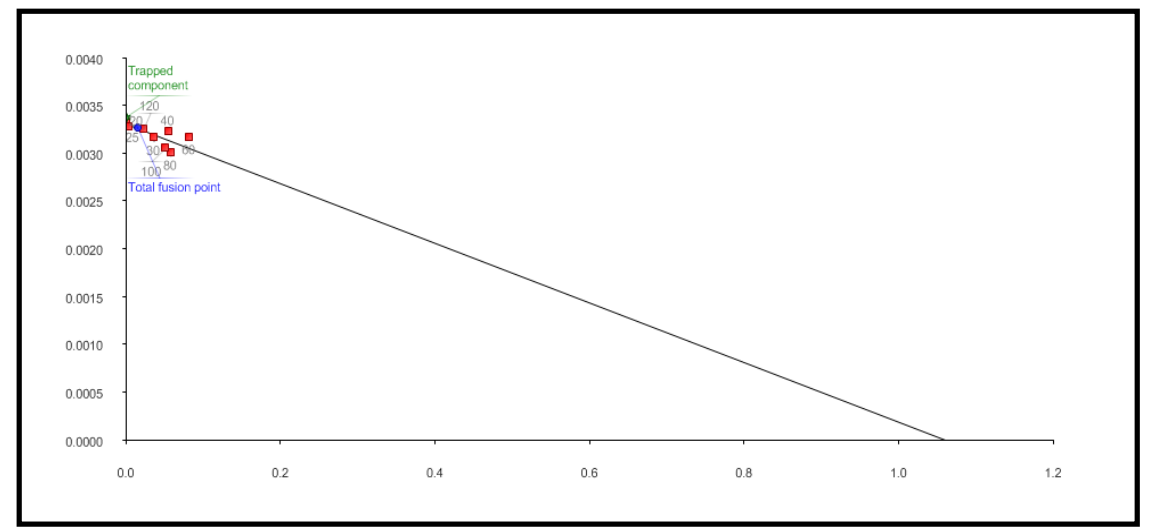

Fig.5a: The Inverse Isochron of the Sample collected from Cone 7 at Kassa Volcanic Field 


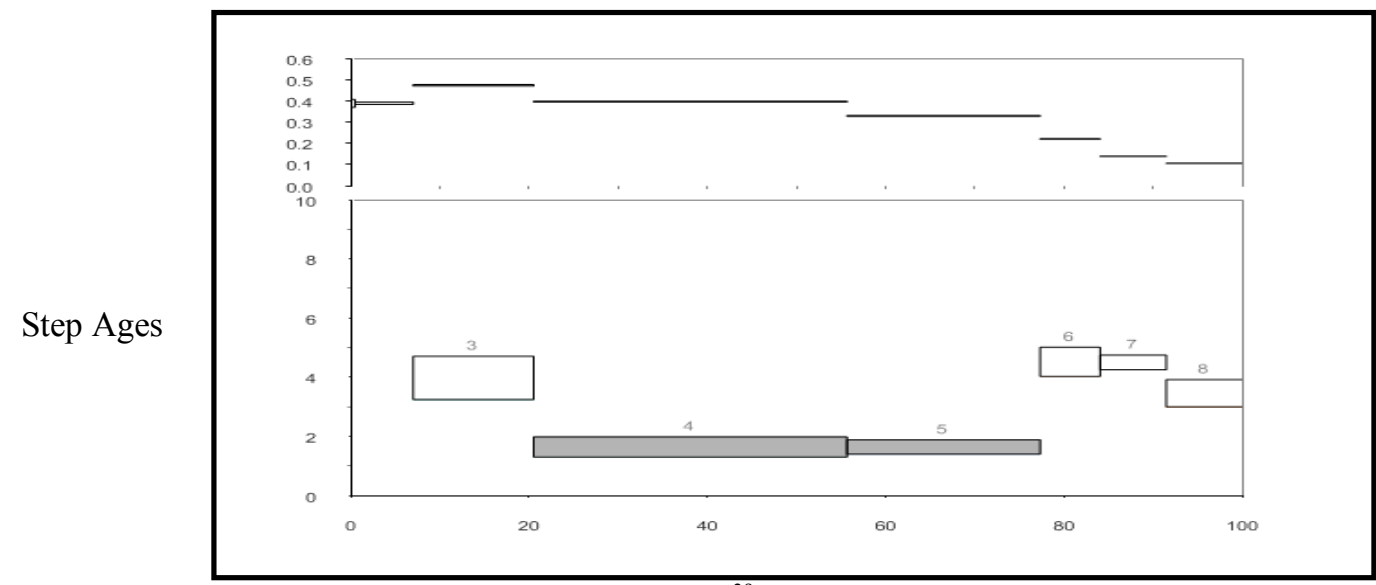

Cumulative $\%{ }^{39} \mathrm{Ar}$

(Ma)

Fig.5b: The Age Spectrum of the Sample collected from Cone 7 at Kassa Volcanic Field

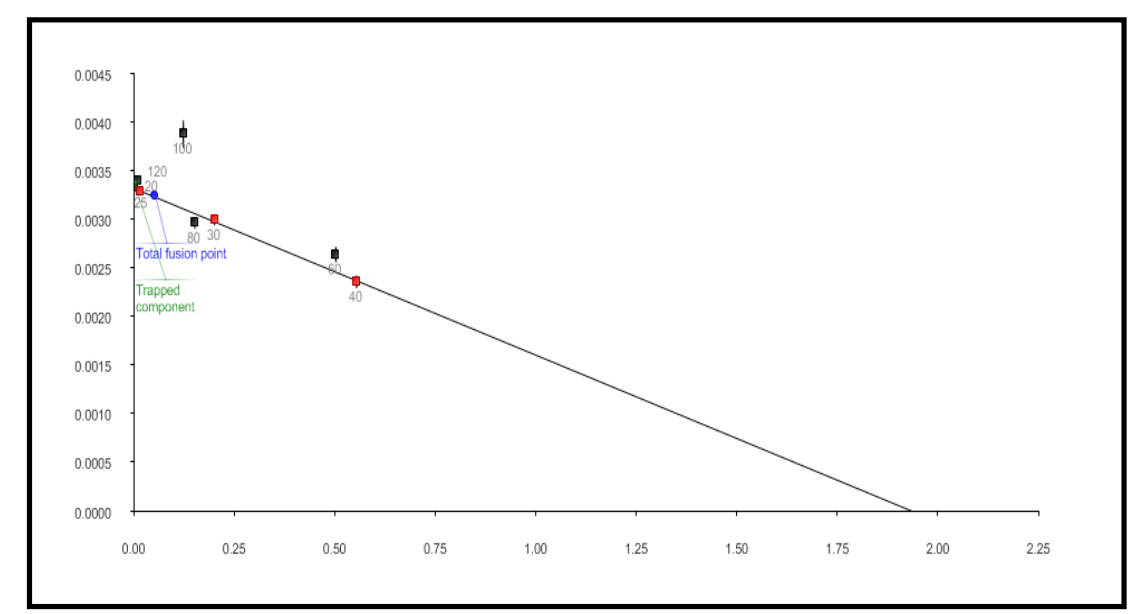

Fig.6a: The Inverse Isochron of the Sample collected from Cone 7 at Kassa Volcanic Field

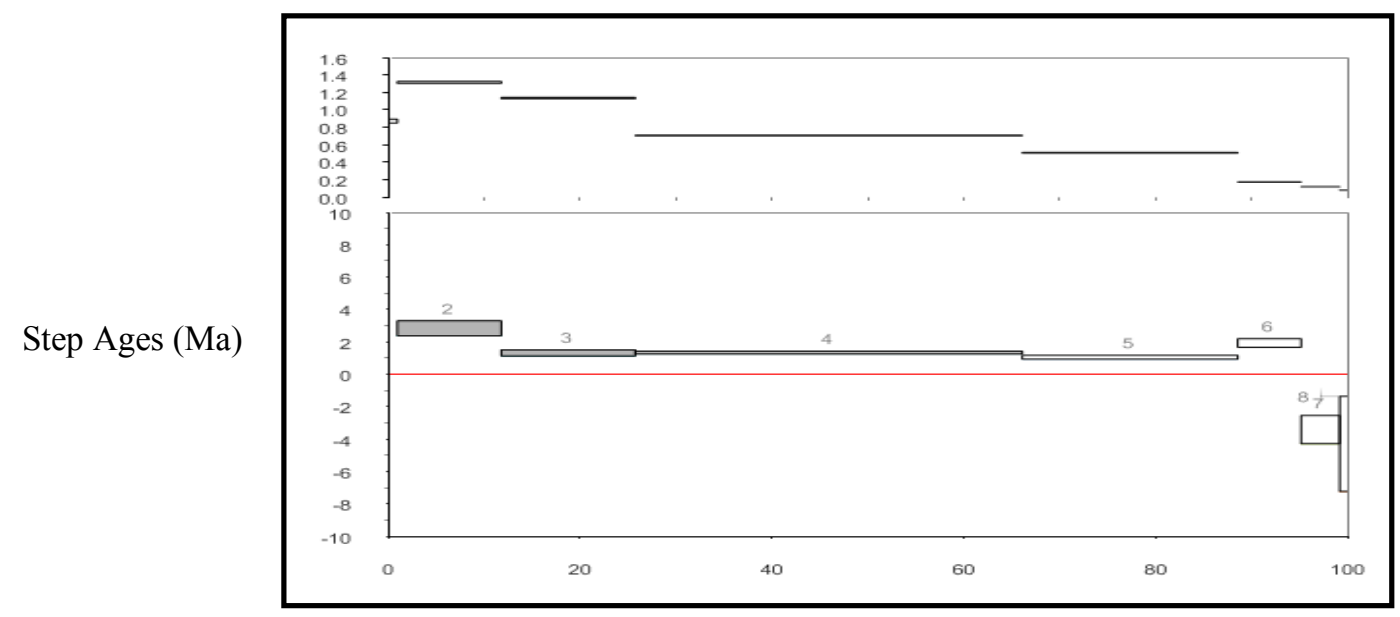

Fig.6b: The Age Spectrum of the Sample collected from Cone 7 at Kassa Volcanic Field

\section{Petrography}

A total of fifteen out of the thirty basaltic lava flows were selected from the cones and cut into thin sections for microscopic studies. Megascopic studies indicate that the rocks consist of reddish brown, iddingsite olivine, and plagioclase and are characterized by medium to fine-grained porphyritic and intergranular textures. Petrographically, under cross and plane polarised lenses, it was observed that the samples consist of the 
following average mineralogical compositions, these are; olivine (40\%), clinopyroxene (35\%), Plagioclase $(15 \%)$, Fe-Ti oxides $(8 \%)$ and opaque minerals $(2 \%)$.

The most mafic rocks contain mainly olivine, clinopyroxene phenocrysts, plagioclase, Fe-Ti oxides and opaque minerals. The plagioclase usually are colourless, elongated and exhibit twining. The extinction angles corresponds to labradorite $\left(\mathrm{An}_{53-58}\right)$. The basalts in the KVF have a porphyritic texture with phenocrysts of olivine $(0.7-2 \mathrm{~mm})$ usually surrounded by Fe-Ti oxides are magnetite and/or ilmenites to a partial iddingsite.This is due alteration from the rim to the core probably due to hydrothermal processes. In most cases not necessary due to weathering activities. The groundmass formed fine-grained (less than $1 \mathrm{~mm}$ ) with an intergranular texture and composed of plagioclase microlites, subhedral to anhedral, brown clinopyroxene, alkali feldspar and $\mathrm{Fe}-\mathrm{Ti}$ oxides. Olivine observed in these samples are Mg-rich olivine occurs as dominant phenocryst phase. The crystals are generally homogeneous, but can have mg-rich cores and less magnesium rims (Fig.7A). Ca-rich pyroxene occurs in the basalts of the KVF. The phenocrysts are rich in aluminium $\left(4.5-7 \mathrm{wt} \% \mathrm{Al}_{2} \mathrm{O}_{3}\right)$ and titanium (1.8-4.8 $\left.\mathrm{wt} \% \mathrm{TiO}_{2}\right)$. The highest $\mathrm{Fe}$ and $\mathrm{Ti}$ contents are being presents particularly in the rims of olivine and also on the groundmass (Fig.7A).The constituent rock types are the olivine basalts and tend to be abundant more towards the northern extremity of the KVF.
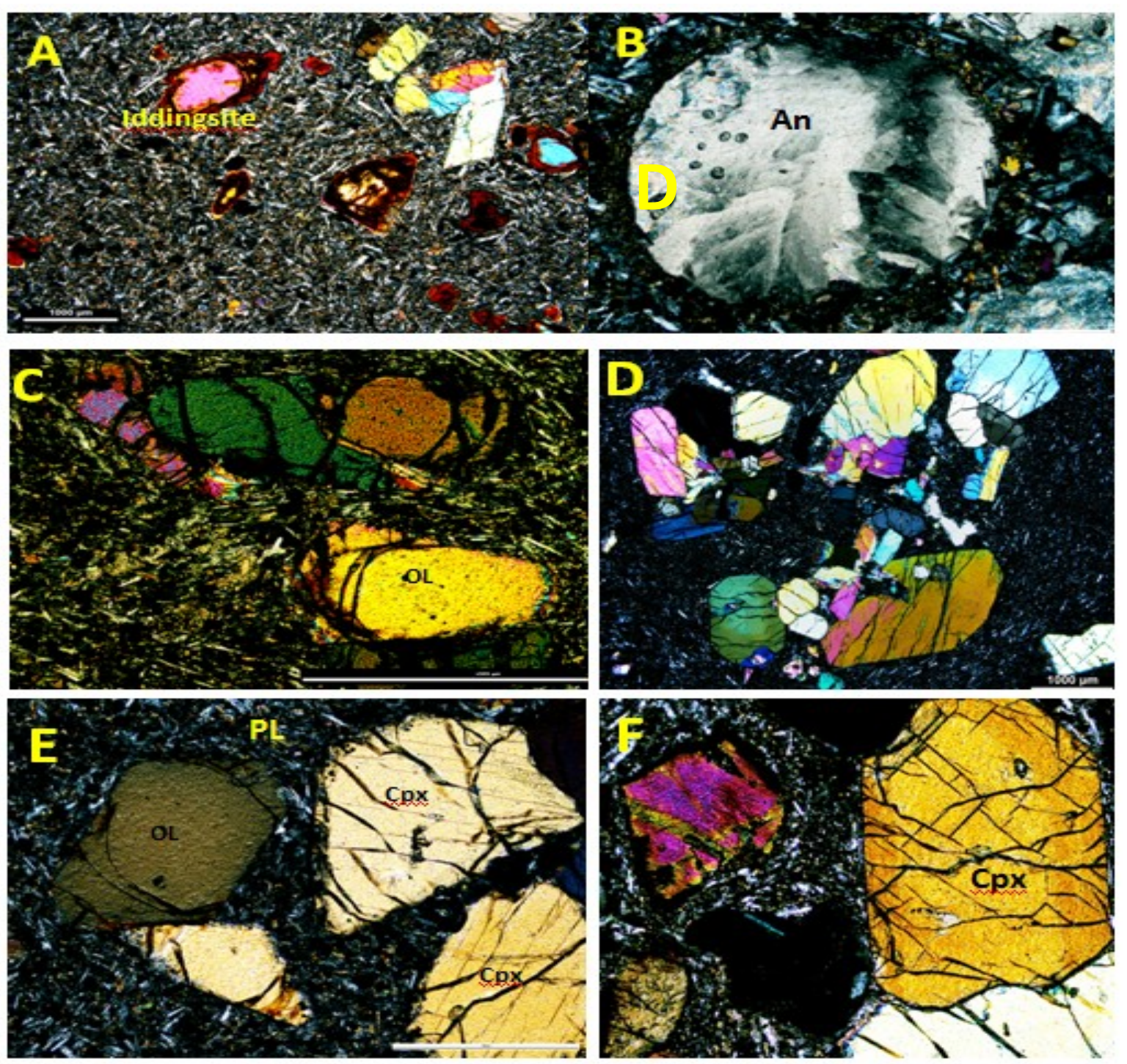

Fig. 7A-F: The Representative photomicrographs of the volcanic lava flows from the Kassa Volcanic Field. (A) Olivine at the top of the photograph been surrounded by rim of Fe-Ti oxides (iddingsite). (B) Analcite mineral originated due to hydrothermal processes. (C) Olivine and plagioclase flow at the groundmass. (D) Very fine plagioclase form the groundmass with clinopyroxene displaying twining. (E) Olivine and clinopyroxene revealing prominent fractures and plagioclase and opaque minerals forming the groundmass. (F) Prominent phenocryst of clinopyroxene with fractures. (All under XPL,1000 $\mu$ )

$\boldsymbol{P L}=$ Plagioclase, $\boldsymbol{O l}=$ Olivine, $\boldsymbol{C p \boldsymbol { x }}=$ Clinopyroxene, $\boldsymbol{A n}$ - Analcite 


\section{Geochemistry}

Major and trace element compositions of selected representative samples of the Kassa Volcanic lava series are presented in Table 1. The olivine basalts all belong to the alkaline series. Basaltic lavas have moderate $\mathrm{MgO}$ contents (8.69 to $11.08 \mathrm{wt} . \%)$. These intermediate lavas disrupt the clear bimodality of the series, contrarily to what has been observed on the Benue Trough (Ngounouno et al., 2000). This is not an artefact resulting from weathering because these lavas are petrographically fresh (as attested by microscope observation) and have rather low LOI contents, as all other lavas.

\section{Analytical Methods}

Thirty representative samples of both plutonic and volcanic rocks have been analyzed at the University of Cardiff, Wales for major elements and Rare Earths Elements (REEs), and the trace elements were analyzed at the University of Leicester. Major elements and trace elements analyses have been made by ICP-OES (Inductively Coupled Plasma-Optical Emission Spectrometry) and ICP-MS (Mass Spectrometry) methods respectively. International geo- standards have been used and details of the methods are available in Weis and Frey (1991), Benoit et al., (1996) and Aries et al., (2000). The Standard deviation for trace elements analysis was typically below 2 wt. $\%, 0.92$ wt. $\%$ for $\mathrm{SiO}_{2}, 326.6$ ppm for $\mathrm{TiO}_{2}, 0.45$ wt. $\%$ for $\mathrm{Al}_{2} \mathrm{O}_{3}, 0.09$ wt. $\%$ for $\mathrm{Fe}_{2} \mathrm{O}_{3}, 75.55$ ppm for $\mathrm{MnO}, 0.14$ wt. $\%$ for $\mathrm{MgO}, 0.26$ wt. $\%$ for $\mathrm{CaO}, 0.19$ wt. $\%$ for $\mathrm{Na}_{2} \mathrm{O}, 753.10$ ppm for $\mathrm{K}_{2} \mathrm{O}$ and $249.50 \mathrm{ppm}$ for $\mathrm{P}_{2} \mathrm{O}_{5}$. The detection limits for trace elements range from $0.01 \mathrm{ppm}$ (REE) to $20 \mathrm{ppm}(\mathrm{Zr}$ ).

Mineral compositions have been analyzed using microprobe with a CAMECA SX 50, at the School of Earth Sciences, University of Bristol, UK. The analytical conditions were $15 \mathrm{kV}$ for the acceleration tension and the beam size was $2 \times 2 \mu \mathrm{m}$ under 10 or $20 \eta \mathrm{A}$, according to resistance of mineral to the electronic beam. Acquisition times were $10 \mathrm{~s}$ for the peak, and $5 \mathrm{~s}$ on both sides of the peak, for an analyzed volume of $5 \mu \mathrm{m} 3$. Ka lines were used.

\section{Major and Trace Elements}

Major and trace element distributions vs. Rb content are presented in Fig. 8A-E. Rubidium has been used as a Differentiation Index (DI) because of its large range of variation (from $30 \mathrm{ppm}$ in basalts to $518.2 \mathrm{ppm}$ in biotite granite), and because this element is strongly incompatible and is excluded from the fractionation processes.

Silica content increases with differentiation in all basalts in the study area. $\mathrm{TiO}_{2}, \mathrm{Fe}_{2} \mathrm{O}_{3}{ }^{*}$ and $\mathrm{CaO}$ contents are high in basaltic lavas (3.4, 12.6, and $11.2 \mathrm{wt} \%$ respectively) and decrease strongly in felsic lavas. $\mathrm{MgO}$ and $\mathrm{P}_{2} \mathrm{O}_{5}$ also increase slightly: the $\mathrm{MgO}$ content is typically more than $11.08 \mathrm{wt} \%$, and the $\mathrm{P}_{2} \mathrm{O}_{5}$ content less than 0.40 $\mathrm{wt} \%$ in felsic lavas (except in biotite-bearing granite). The aluminium content is low in basalts $\left(\mathrm{Al}_{2} \mathrm{O}_{3}\right.$ wt. \% 15.2). The $\mathrm{Na}_{2} \mathrm{O}$ contents and $\mathrm{Rb}$ concentrations $(40 \mathrm{ppm})$ in basalts are similar to those for other basalts from the Biu Plateau.

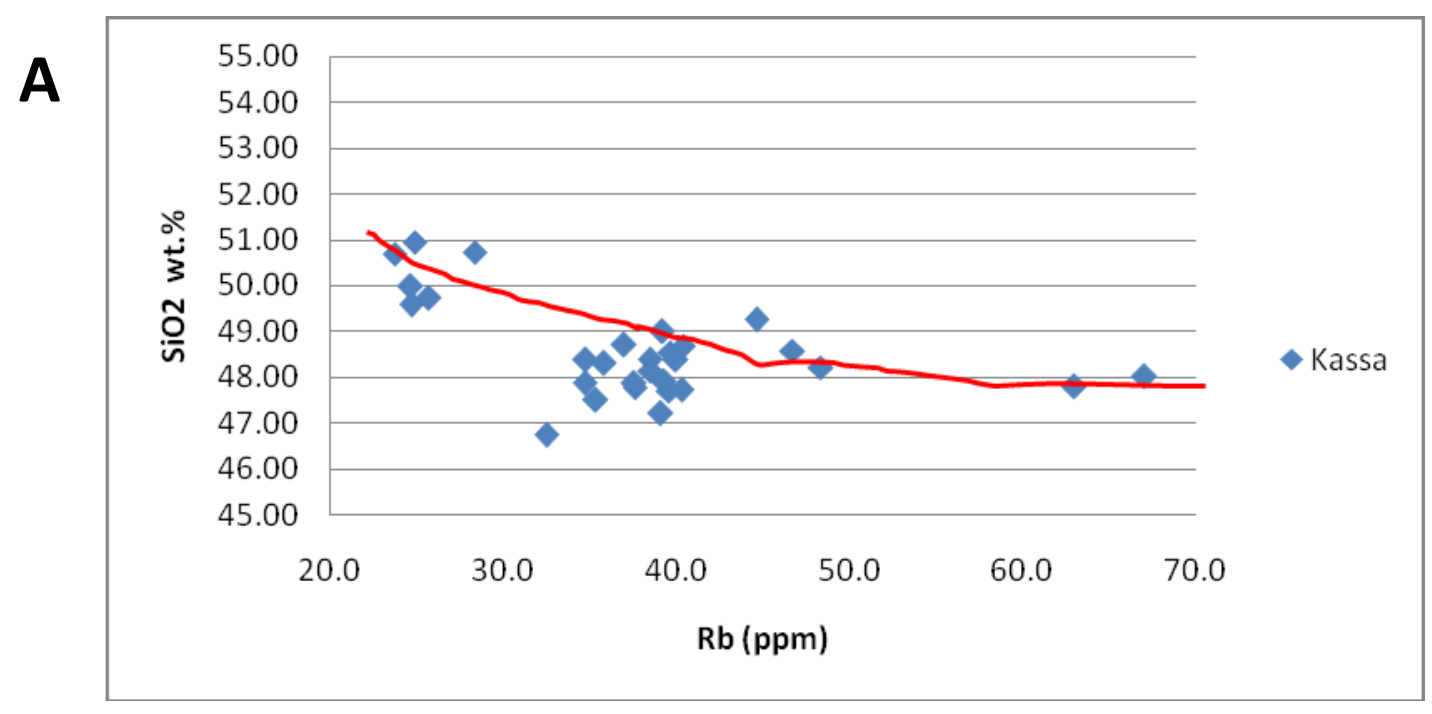



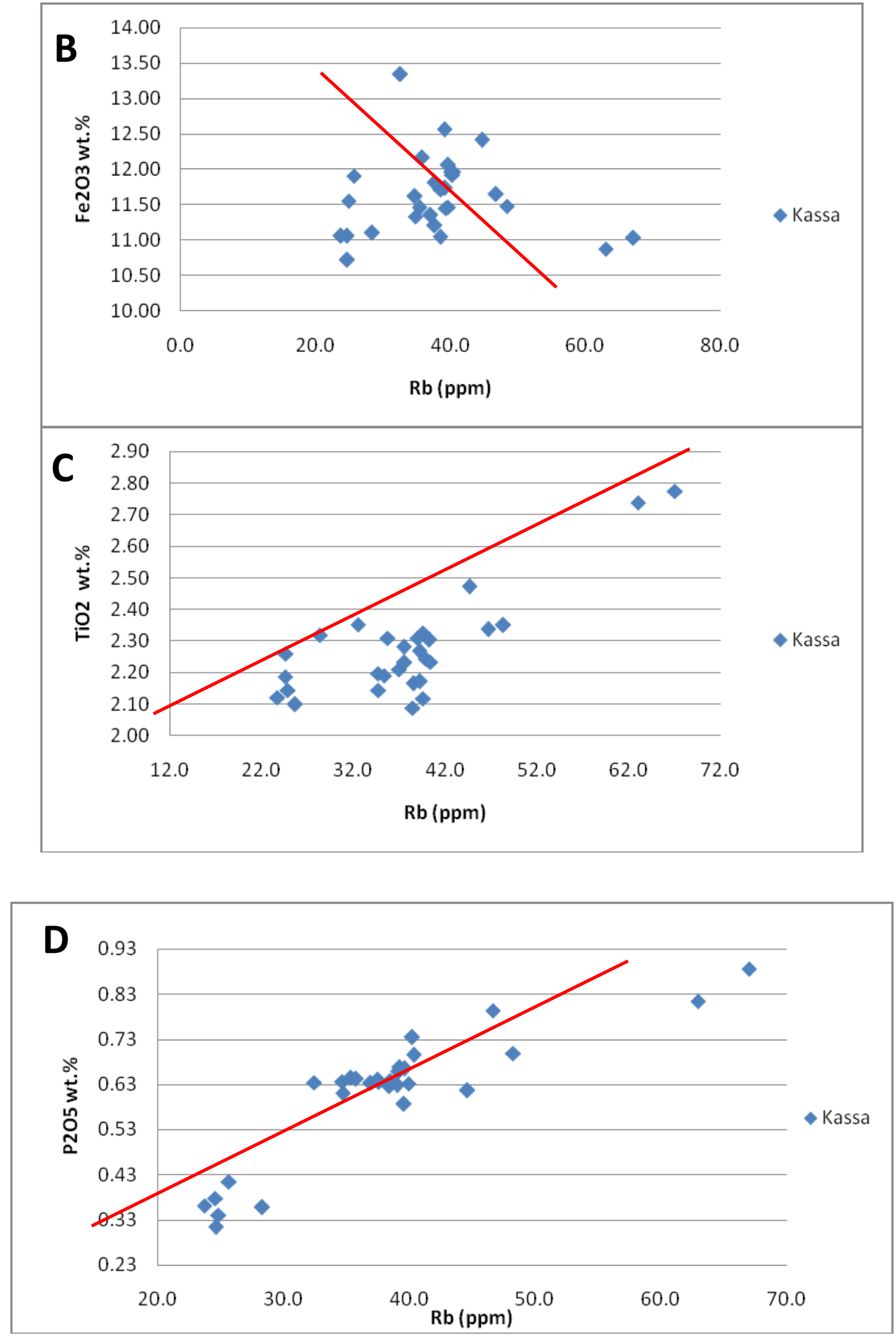


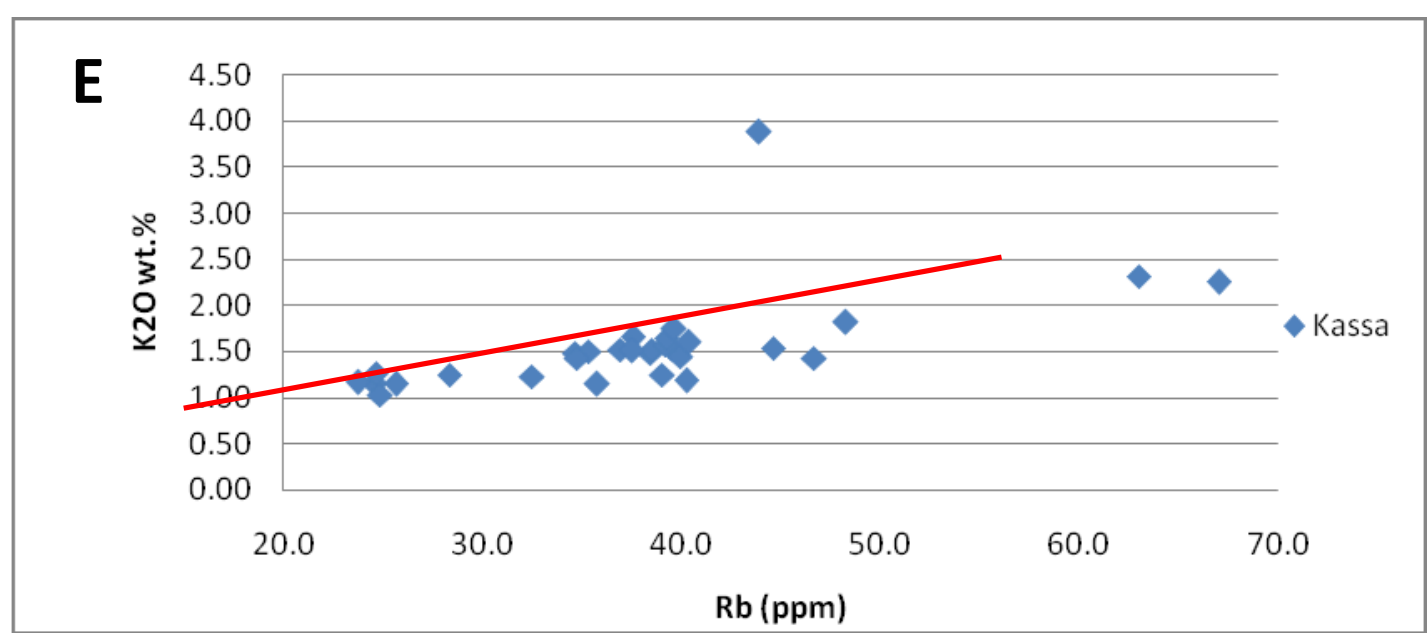

Fig.8A-E: The Plots of $\mathrm{Rb}$ versus some Major Element oxides of the basaltic rocks from Kassa Volcanic Field (the study area)

The $\mathrm{K}_{2} \mathrm{O}$ content increases from basalts and granites $\left(1.2<\mathrm{K}_{2} \mathrm{O}\right.$ wt. $\left.\%<2.3\right)$ to biotite-bearing trachytes (up to 6.0 $\mathrm{wt} \%$ ). Some of the basalts have high transition metal element contents ( $\mathrm{Ni}$ and $\mathrm{Cr} \mathrm{ppm}>200$, Co ppm $>40$, and Sc ppm $>20$ ); The other sample (Biotite Granite) have very low contents of these elements and have lavas with abundance of metal transition elements $(\mathrm{V}, \mathrm{Cu}, \mathrm{Cr}, \mathrm{Co}$, and $\mathrm{Ni})$.

Biotite-bearing granite reveal high Ba contents $(>1,200 \mathrm{ppm})$ and moderate to low Sr contents $(87-67$ ppm). Contents in zirconium in present in the biotite granite, identified from the Scanning Electron Microprobe and trace element analysis $(250$ to $500 \mathrm{ppm})$. The basaltic rocks have drastically lower $\mathrm{Zr} / \mathrm{Nb}$ ratios (1.7), possibly due to aegirine-augite (up to $1.07 \mathrm{wt} \% \mathrm{ZrO}_{2}$ ) and aenigmatite (up to $0.16 \mathrm{wt} \% \mathrm{ZrO}_{2}$ ) fractionation in the peralkaline trachyte magma. Yttrium contents range between 20 and 54 ppm for all the lavas (biotite-bearing granites having the highest $\mathrm{Y}$ contents of about 213ppm). Concentrations in $\mathrm{Yb}$ are higher in felsic lavas than in basaltic ones, except in biotite-bearing lavas (Table 2).

\section{Major Elements}

Generally, the basaltic rocks display little variation in their major elements compositions. The $\mathrm{SiO}_{2}$ wt. \% ranges between 46.83 - 50.95 wt. \% in most of the rocks studied. $\mathrm{Al}_{2} \mathrm{O}_{3}$ wt.\% ranges from 12.6 wt. $\%$ (KSS 37) to 16.8 wt.\%(KSS 5), while MgO wt.\% vary from 3.2 wt.\% (KSS 24) to 8.9 wt.\% (KSS 22 and KSS 7). Samples KSS 22 and KSS 7 has the highest MgO wt \% (8.9 wt.\%) and sample KSS 24 with the lowest $\mathrm{SiO}_{2}$ wt $\%(47.2$ w.t $\%)$.

It was observed that almost all the rocks in KVF display a very low concentration in MnO wt.\%. The variation ranges from $0.02 \mathrm{wt} . \%$ (KSS 39) to $0.18 \mathrm{wt} . \%$ (KSS 34) and KSS 8). The sample (KSS 39) with the lowest wt. $\%$ is a granitic rock and $\mathrm{KSS} 34$ and $\mathrm{KSS} 8$ have the highest $\mathrm{MnO}$ wt $\%$ concentrations. The $\mathrm{K}_{2} \mathrm{O}$ wt $\%$ ranges between 1.02 wt. $\%$ (KSS 43) and $1.7 \mathrm{wt} \%$ (KSS2). $\mathrm{Fe}_{2} \mathrm{O}_{3}$ wt $\%$ ranges between 10.74 wt.\% (KSS 5) and 13.34 wt.\% (KSS 34). The variation in $\mathrm{TiO}_{2} \mathrm{wt} \%$ ranges from 0.03 wt.\% (KSS 39) to 2.75 wt.\% (KSS 29).

Major elements concentrations were plotted on different variations diagrams. It is also observed that almost all the rocks in KVF have similar composition, mode of occurrences and colour but different textures except sample 39 which is believe to be Biotite Granite (host rock).

\section{$\mathrm{SiO}_{2}$ wt.\% versus some Selected Major Elements}

The Harker's variation diagrams are useful tools in interpretating the petrogenesis and tectonic setting of most igneous and metamorphic rocks (Harker, 1977) Therefore, in this study oxide variation in relation to silica $\left(\mathrm{SiO}_{2}\right)$ contents is diagrammatically presented in figures $\left.9 \mathrm{a}-\mathrm{f}\right)$. The presumption that is the course of evolution in a cogenitic magma series, there is continuous increase in $\mathrm{SiO}_{2}$ content makes the variation diagram to have a direct evolutionary significance.

These variation plots are shown in figures $4.18 \mathrm{a}-\mathrm{f}$ ) on the $\mathrm{SiO}_{2}$ wt.\% versus $\mathrm{Fe}_{2} \mathrm{O}_{3}$ wt. $\%$ and $\mathrm{TiO}_{2}$ wt $\%$ plots (Fig. 9a and b), the rocks appear to falls into two main groups. The first group is those with high $\mathrm{Fe}_{2} \mathrm{O}_{3}$ wt $\%$ content (KSS 34, KSS 29, KSS 40, KSS 2, KSS 8, KSS 37, and KSS 13) while those with low $\mathrm{Fe}_{2} \mathrm{O}_{3}$ wt. $\%$ (KSS 38, KSS 3, KSS 5, KSS 26 etc) falls at the base of the graph (Fig.4.19a). Both groups have $\mathrm{SiO}_{2}$ wt. $\%$ that vary within narrow limits. The pattern displayed by the rocks on the $\mathrm{SiO}_{2} \mathrm{wt} . \%$ versus $\mathrm{MgO} \mathrm{wt} \%$ plot (Fig. 9d) is comparable to that seen in the $\mathrm{SiO}_{2}$ wt.\% versus $\mathrm{TiO}_{2}$ wt.\% plot.

The samples collected from Cone 1(KSS 22, KSS 15,KSS 32 and KSS 12), from Cone 2 ( KSS 16,KSS 5, KSS 6KSS 17 and KSS 7), Cone 3 (KSS 19,KSS 43, KSS 50 and KSS3), Cone 4 (KSS 34,KSS 23,KSS 26 and KSS 
8), Cone 5 (KSS 28,KSS 42,KSS 4), Cone 6(KSS 29, KSS 40, KSS 41), Cone 7(KSS 2, KSS 8, KSS 37, KSS 14) and Cone 8 (KSS 38, KSS 5, KSS 9).

In the $\mathrm{SiO}_{2}$ wt. $\%$ Versus $\mathrm{CaO}$ wt.\%, $\mathrm{MgO}$ wt. $\%$ and $\mathrm{Fe}_{2} \mathrm{O}_{3}$ wt.\% a general positive correlation is observed in each case. The samples displayed similar pattern of distribution as in $\mathrm{SiO}_{2}$ wt.\% versus $\mathrm{TiO}_{2}$ wt.\% diagrams (Fig. 9 e).

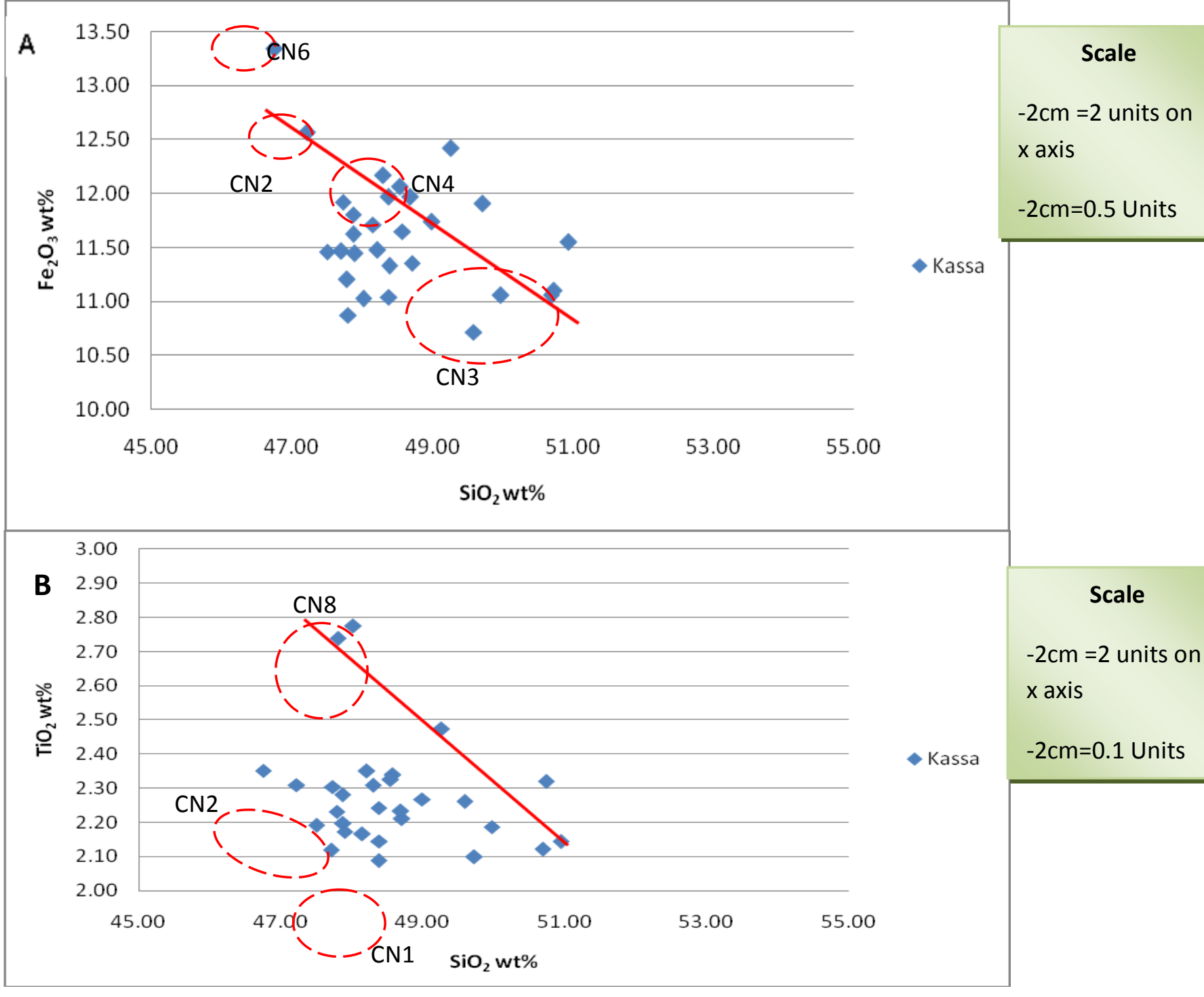


The Geochemistry and Geochronology of the Quaternary Volcanism of the Kassa Volcanic Field

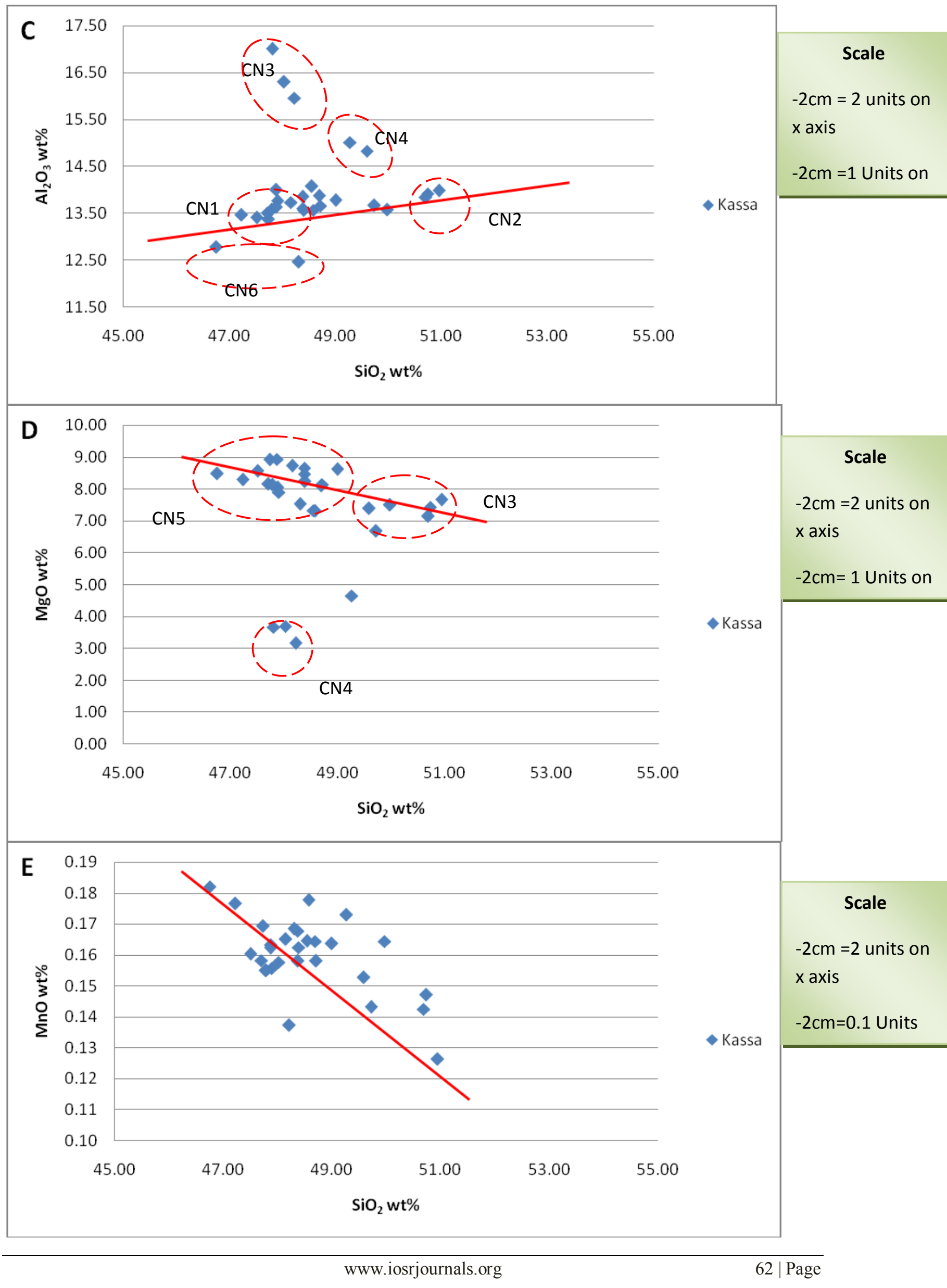


The Geochemistry and Geochronology of the Quaternary Volcanism of the Kassa Volcanic Field

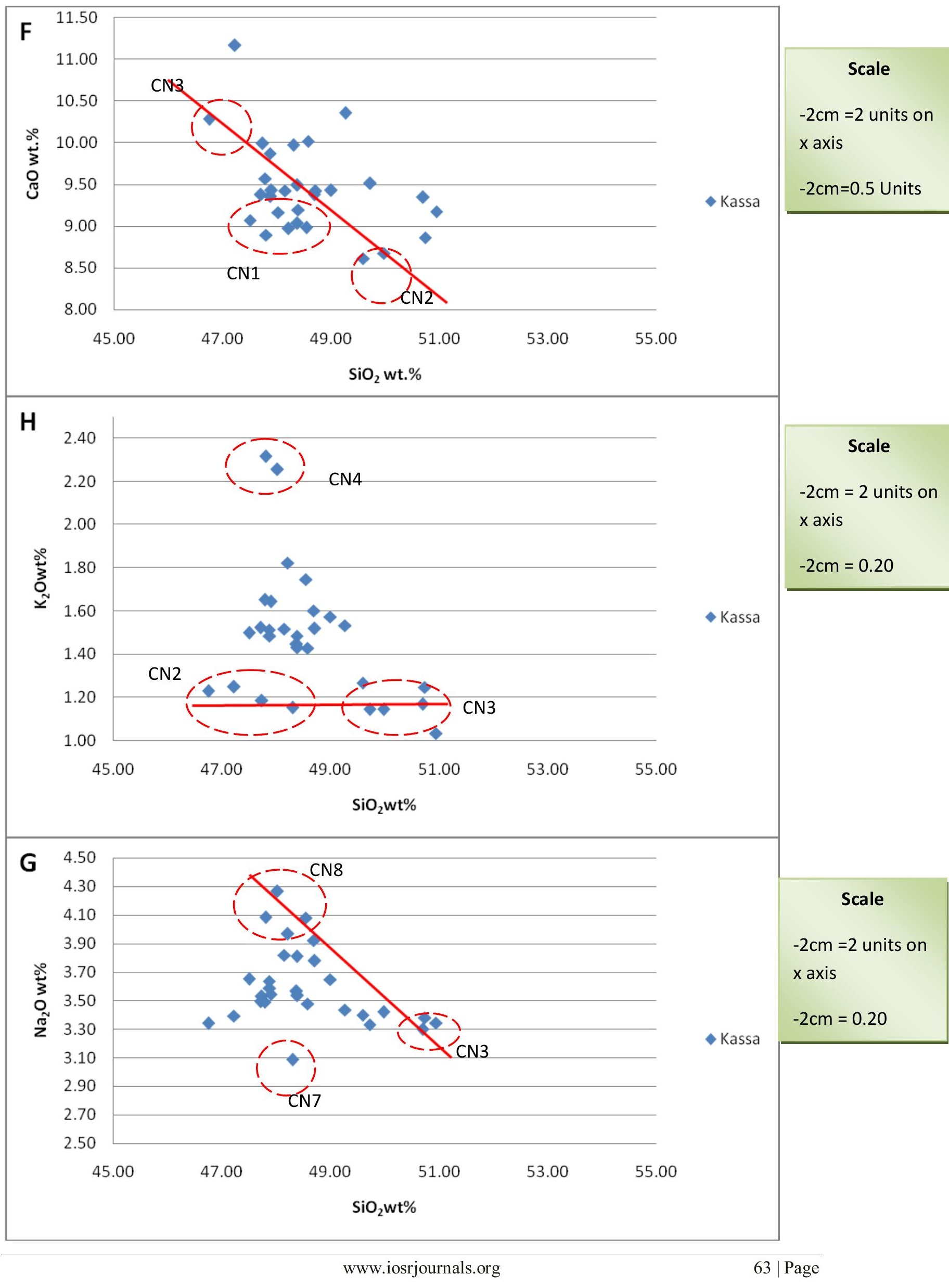


The Geochemistry and Geochronology of the Quaternary Volcanism of the Kassa Volcanic Field

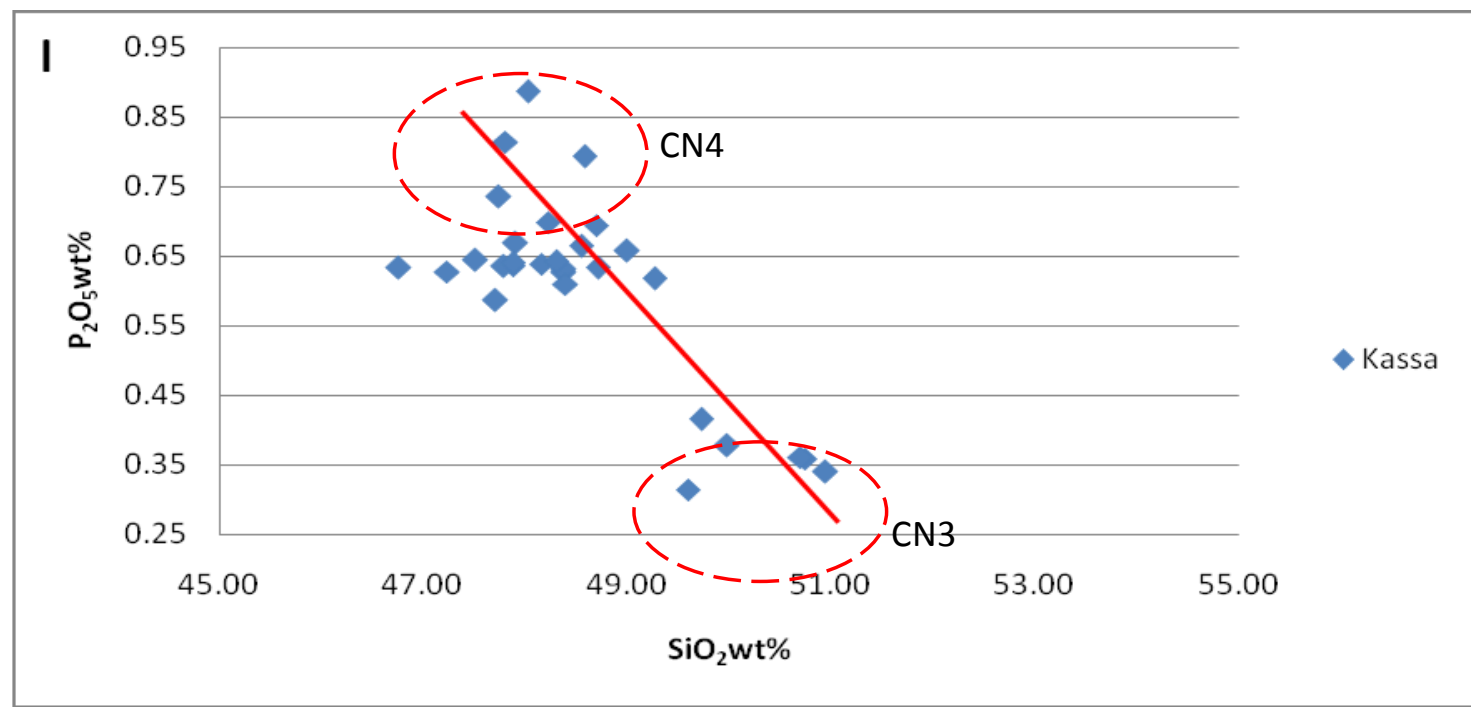

Fig. 9a-i: The Variations Diagrams of $\mathrm{SiO}_{2}$ wt.\% versus Major Elements oxides of the basaltic rocks from the Kassa Volcanic Field (KVF).

Table 1: THE MAJOR ELEMENTS ANALYSES OF REPRESENTATIVE SAMPLE FROM KASSA VOLCANIC FIELD (KVF)

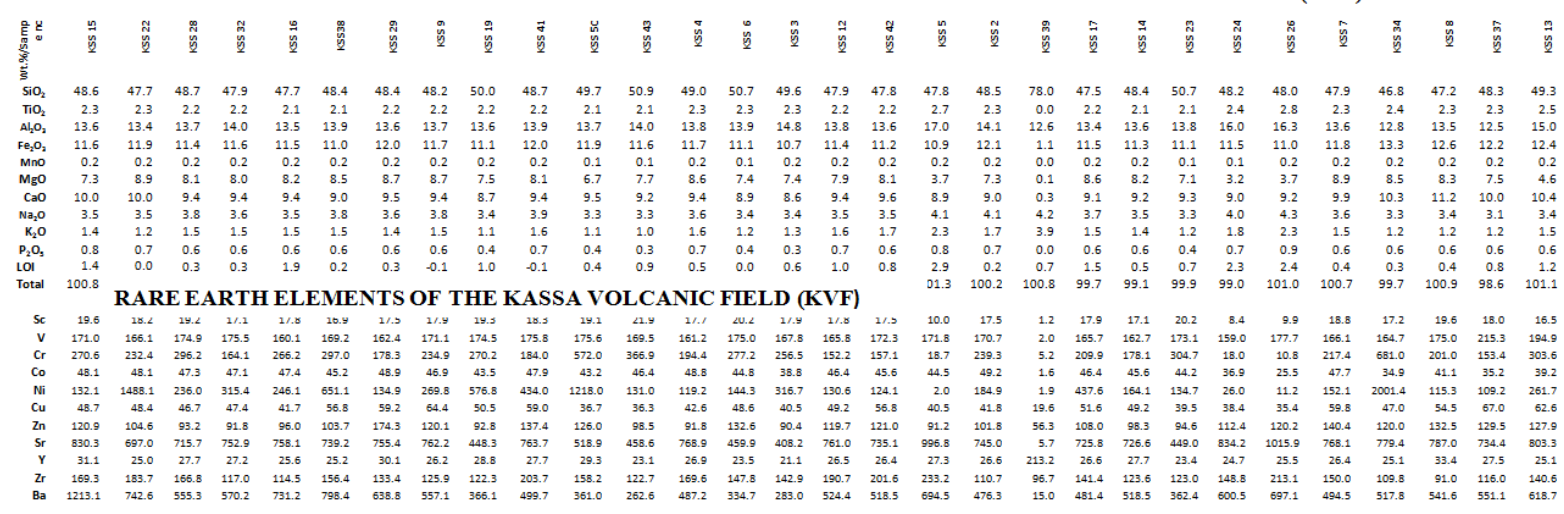

Table 2: TRACE ELEMENTS CHEMICAL ANALYSES OF REPRESENTATIVE SAMPLES FROM KASSA VOLCANIC FIELD (KVF)

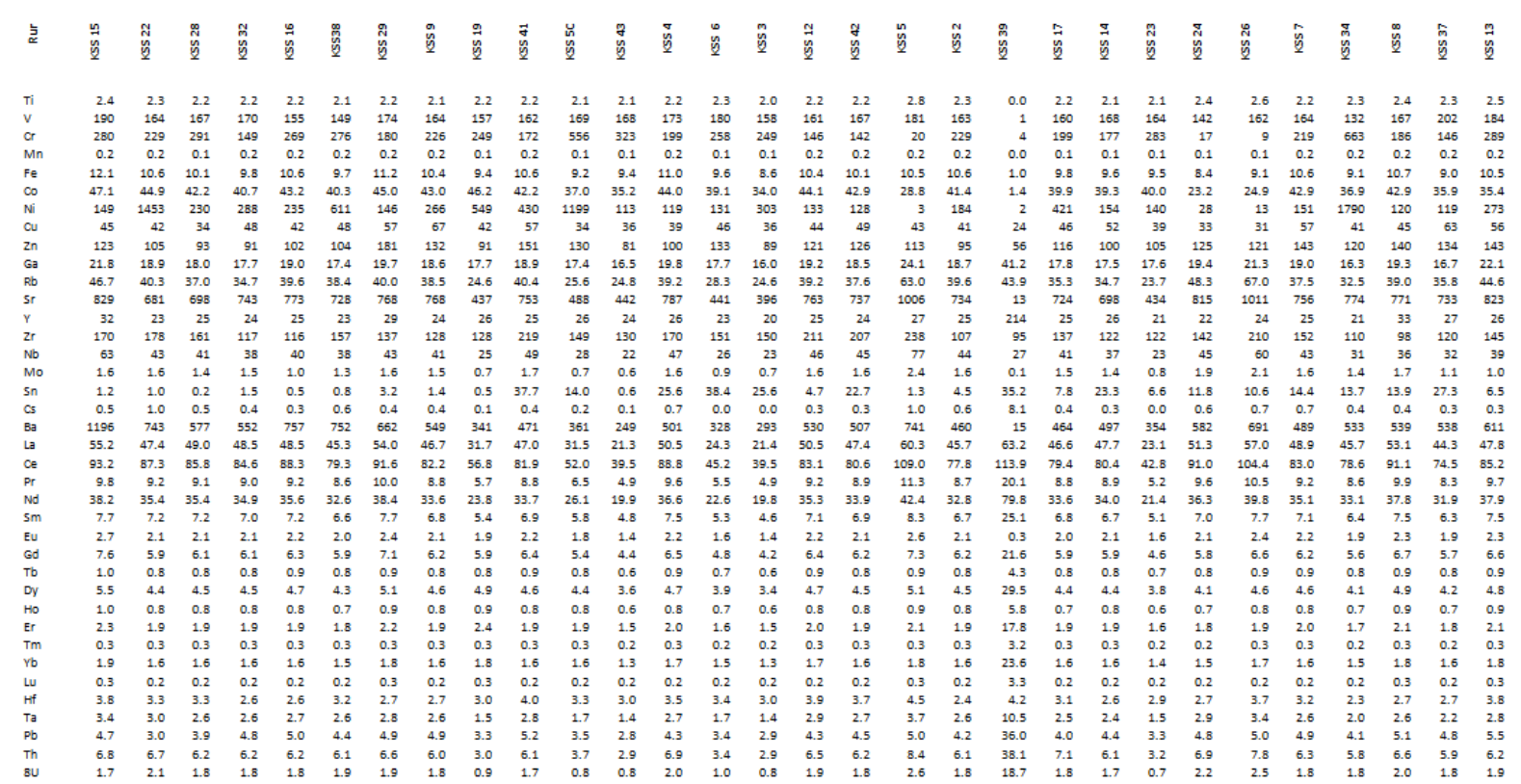

\section{Trace Elements}

The amounts of $\mathrm{Ni}, \mathrm{Cu}, \mathrm{Zn}, \mathrm{Y}, \mathrm{Ga}, \mathrm{Pb}$ and $\mathrm{Sn}$ vary considerably from mafic to felsic rocks. The variation of incompatible trace elements is marked by the increase of $\mathrm{Zr}, \mathrm{Rb}, \mathrm{Nb}$ and $\mathrm{Th}$ from mafic to felsic 
rocks (Fig.5). The distribution of selected trace elements relative to Th contents is shown in figure $8 \mathrm{~b}$. The $\mathrm{Rb}$ contents are significantly higher in felsic rocks than in the mafic lavas. $\mathrm{Zr}, \mathrm{Nb}, \mathrm{Rb}, \mathrm{Y}, \mathrm{Yb}, \mathrm{La}$ and $\mathrm{Ta}$ show a positive correlation with $\mathrm{Th}$ contents with a linear trend for $\mathrm{Nb}$ and $\mathrm{Zr}$, contrary to $\mathrm{Sr}$ and $\mathrm{V}$. The $\mathrm{Sr}$ contents decrease from mafic lavas (1241.6-790.7 ppm) to felsic rocks ( $<236 \mathrm{ppm})$.

Chemical analyses of 30 representative samples place KVF in sub-akaline, calc-alkaline magma series (see Figure 10), supporting the assumption that these volcanic are subduction - related activities. $\mathrm{SiO}_{2}$ ranges from 44 to $50 \% ; \mathrm{TiO}_{2}$ from 0.5 to $1 \% ; \mathrm{Al}_{2} \mathrm{O}_{3}$ from 17 to $19 \% ; \mathrm{FeO}^{*}$ from 5 to $8 \% ; \mathrm{MgO}$ from 3 to $6 \% ; \mathrm{CaO}$ from 5 to $8 \%$; Alkalis from 4 to $6 \% ; \mathrm{P}_{2} \mathrm{O}_{5}$ from 0.2 to $0.6 \%$. Samples are plotted in normal basalts domain according to LeBas et al., 1986) and medium $-\mathrm{K}$ basalt and andesites according to Rickwood and Guilford (1981). One sample from KVF was collected from south-eastern portion is biotite granite and was plotted in the tholeiitic field.

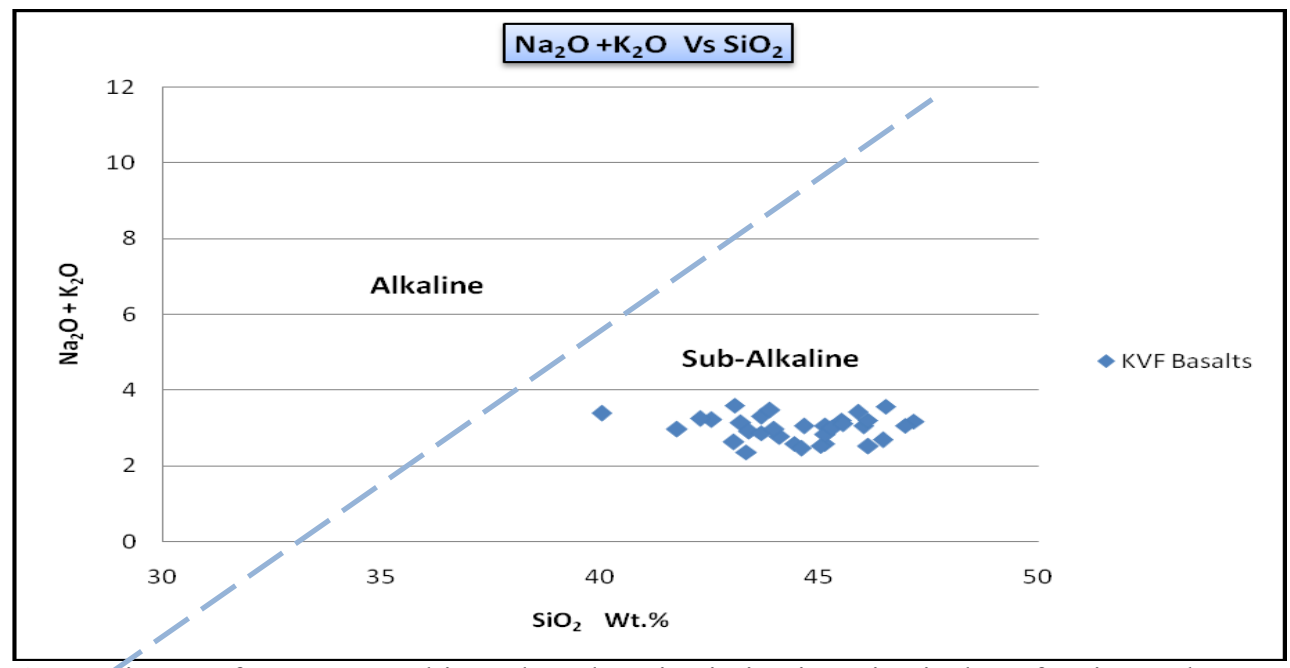

Fig. 10: AFM Diagram for KVF Basaltic rocks. The Discrimination Line is that of Irvine and Baragar (1971

\section{Total Alkaline and Silicate (TAS) Discrimination Diagram}

In the $\left(\mathrm{Na}_{2} \mathrm{O}+\mathrm{K}_{2} \mathrm{O}\right)$ versus $\mathrm{SiO}_{2}$ wt. \% variation diagram of Le Bas et al., (1986) (Fig.11), mafic lavas fall in the field of basalt, while felsic rock correspond to rhyolite. The TAS diagram shows a sub-alkaline character and belonging to the medium - K calc- alkaline magma series (Rickwood 1986). There are some chemical differences between the basaltic rocks collected from the northern part of the KVF and the southern extremity of the study area. The samples from cone 1,2 and 4 are plotted near the boundary between basalt and the basaltic andesite domain. The only sample plot in the rhyolite field is KSS 39 which was collected from the biotite granite rock outside cone 2 within the Basement rock.

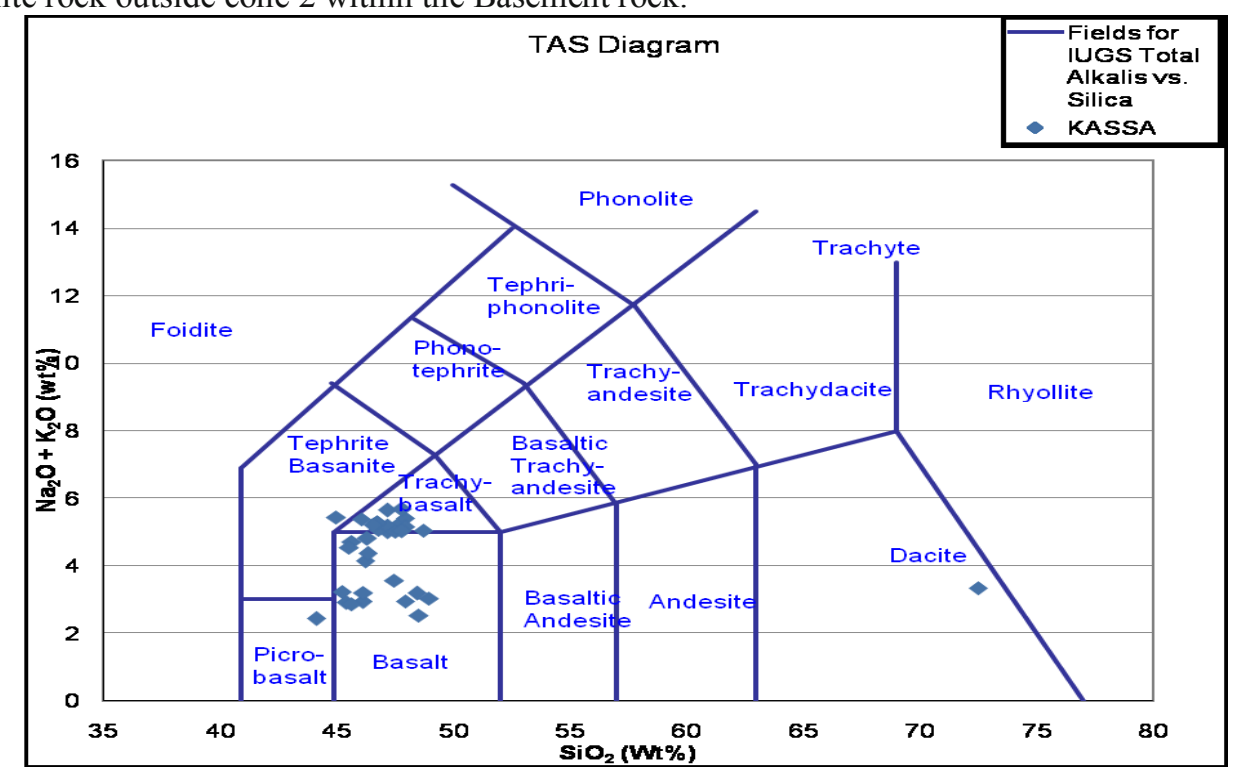

Fig. 11: Total alkali-Silica (wt.\%) diagram according to Le Bas et al., (1986). The KVF recent formations fall mainly in basalt and trachytic basalt fields while the basement rock falls within the dacite domain. 


\section{Discussion}

The basaltic rocks studied in the Kassa Volcanic Field (KVF) can be discussed from different approaches that were employed in the research. These approaches are geological mapping, petrology, Geochronology, geophysical survey and remote sensing techniques.

Petrographically, these rocks are typical of continenta1 alkaline-olivine basalts. They contain varying amounts of olivine, titanaugite and less commonly calcic plagioclase in a groundmass of the minerals plus opaque oxides and occasionally some interstitial brownish glass. These petrographic characteristics are consistent with the geochemical characteristics of the rocks which are composed of high $\mathrm{Fe}_{2} \mathrm{O}_{3}, \mathrm{TiO}_{2}$ and $\mathrm{MgO}$ and hence are distinctly calc - alkaline.

The geochemical data obtained, when plotted in an AFM diagram (after Irvine and Baragar, 1971) fall within the domain of calc- alkaline magma (Fig 4.21) and one sample (KSS 39) extending into the tholeiitic domain. This suggests that most of the basalts of the KVF are calc-alkaline basalts. Also the data plotted in $\mathrm{Zr}$, Ti-Nb triangular diagram (Pearce and Cann, 1973), and $\mathrm{K}_{2} \mathrm{O}-\mathrm{TiO}_{2}-\mathrm{P}_{2} \mathrm{O}_{2}$ clearly confirms the emplacement of these basalts within the continental crust, ie non- oceanic domain (Fig. 4.25).

In the variation diagram $\left(\mathrm{Na}_{2} \mathrm{O}-\mathrm{K}_{2} \mathrm{O}\right.$ wt.\% versus $\mathrm{SiO}_{2}$ wt.\% $1 \mathrm{ike}$ in the AFM diagram, the samples plot in the alkali to sub-alkali fields suggesting the source magma was alkaline (Fig. 4.27). The Basaltic rocks generally display limited variation in their major element composition. In comparison with the Mid-Oceanic Ridge Basalt (MORB), Biu-Plateau and the basaltic rocks of the Jos-Plateau exhibit rather high concentrations in $\mathrm{Fe}_{2} \mathrm{O}_{3}$ wt.\% $\mathrm{CaO}$ wt.\%, $\mathrm{MgO}$ wt.\% and $\mathrm{TiO}_{2}$ wt.\% (Fig 4.8a-e). Compared to basalts of the Biu Plateau, the Jos Plateau basalt differ by their higher $\mathrm{MgO}$ wt.\% abundances (15 - 23\%) (Biu Plateau 5 - 10\%), higher $\mathrm{Fe}_{2} \mathrm{O}_{3}$ wt.\% (9.6 - 14\%) (Biu Plateau $2.4-4.8 \%$ ). However, the Island arc distinctively low-in $\mathrm{TiO}_{2:}$ wt.\% compared to the other basalt. The Jos Plateau basalts are distinctively higher in $\mathrm{Fe}_{2} \mathrm{O}_{3}$ wt.\% and $\mathrm{MgO}$ wt.\% when compared to the Biu Plateau basalts, island arc and MORB (Fig 4.23). They have intermediate IAB composition comparable to the MORB and lower than that from the Biu Plateau basalts and the Island Arc (Fig 4.7e). They however, have similar $\mathrm{CaO}$ wt.\% compositions to the Mid-Oceanic Ridge (MORB) as shown in figure $4.7 \mathrm{~d}$.

\section{Petrogenesis of Lavas}

There is a slight similarities in the isotopic signature of basaltic lava and granitic rocks of the KVF lavas, which is far from those of the Pan-African basement, and the parallel shape of their trace element patterns show that the investigated recent magmatic formations are genetically related, and belong to the same magmatic episode despite the observed compositional "Daly gap"Several criteria can be emphasized in order to discuss the origin of the KVF recent magmatic rocks. The basaltic lavas in the study area are obviously originated from the mantle (occurrence of Fo89-87 olivine and sometimes mantle xenocrysts), the relative low Ni content (179 ppm) of the least evolved lava shows that they erupted from an already differentiated mafic magma. The basalts derived from this magma through crystal fractionation of olivine, clinopyroxene, and Fe-Ti oxides, as it is the case for the Biu Plateau. The similarities of trace-element patterns observed between the KVF basaltic lavas and the other basalts from the continental and oceanic sectors of the CVL (Fitton 1987, Ngounouno et al., 2000, 2003; Kamgang et al., 2008) and of Adamawa are strong arguments in favor of a common mantle source. The above evidence revealed basaltic lavas and trachytes from Kassa are probably related to the same mantlederived magma source according to their similar $\mathrm{Nb} / \mathrm{Th}$ ratio.

The geochronological studies revealed that the basaltic samples collected from the southern extremity of the Kassa Volcanic Field (KVF) revealed that sample CN3 (cone 3) is the oldest volcanic structure of the study area and this is in agreement with the geology of the area where cone CN 3 falls within the Older Basalt (Fig. 2.6). This oldest volcanic eruption episode in KVF was dated at about $2.5 \mathrm{Ma}$ ago. All the $\mathrm{Ar} / \mathrm{Ar}$ ages (1.3 - 2.5Ma obtained from the Kassa Volcanic Field (KVF) confirmed the fact that basaltic volcanism took place specifically in the Quaternary $(2.1$ and $1.9 \pm 0.31 \mathrm{Ma})$ ages as reported by Grant et al., 1972 using K-Ar dating method. Four samples were dated ranges from 1.34-1.97 Ma (CN5 -1.97 Ma, CN7-1.66 Ma, CN6-1.38 Ma and CN8-1.3 Ma) the concordance of the dates above is convincing evidence of the reality volcanic activity of these ages. The latest episode dated volcanic occurrence of KVF corresponds to the volcanic cones is the sample CN8 (cone 8) which dated $1.34 \pm 0.080 \mathrm{Ma}$. The MSWD is 0.673 , on the samples taken from the same stratigraphic position yield ages that they are reproducible and indistinguishable from one another. Probably the best approach of the time of eruption can be given by mean age 1.35 Ma.

Most of the basaltic rocks studied on the Jos Plateau belong to the Tertiary to Quaternary age but those from Kassa Volcanic Field (KVF) are Plestocene and also been classified into Newer and Older Basalts on the basis of mineralogy, geochronology, mode of occurrence, texture, colour, etc. 


\section{Conclusions}

In conclusion, the geochemical, petrographic and geochronologic investigations pinpoint the followings:

- $\quad$ the mineral series is of definite alkaline character;

- the presence of olivine, clinopyroxene, Fe-Ti oxides and plagioclase microlites forming groundmass in the basalts testifies of wall-rock magma interaction in the crust.

- The occurrence of clinopyroxene phenocrysts of the basalts is a strong argument in favour of magma mixing.

- Correlation between differentiation indices and isotopic and some trace element ratios are consistent with assimilation of crustal material during the differentiation, the oldest rocks being the most contaminated.

- Absent of some minerals in the basaltic lava flow indicates how old the rock has been exposed to denudation activities in the study area. Presence of minerals such olivine, pyroxene and garnets in basaltic rock from cone three ( $\mathrm{CN} 3)$ indicates the Newer basaltic lava flow from the KVF (the study area).

\section{Acknowledgements}

We are grateful to the Centre for Geodesy and Geodynamics, Toro for providing part of the fund expended during research visit to the University of Bristol, UK. Unalloyed appreciations go to the management of School of Earth and Sceinces, University of Bristol for giving me the opportunity for the visit and used their Scanning Electron Microprobe and Electron Microprobe Analyzer equipment. Special thanks go to Mr Caleb K. Aluwong for the GIS work and also thanks is due to Mr. Markus Ishaku and Mr. Job Chollom for the geochemical analysis and thin sectioning preparations at the PTDF laboratory of the Geology and Mining Department, University of Jos.

\section{References}

[1]. Grant, N. K., Rex, D. C. and Freeth, S. J. (1972): Potassium-Argon ages and Strontium Isotope Ratio Measurements from Volcanic rocks in Northern Nigeria. Contr. Mineral. Petrol. Vol. 35, pp 277 - 292

[2]. Lar, U.A. and Tsalha, M.S. (2004): Geochemical Characteristics of the Jos Plateau Basalts, Northcentral Nigeria. Global Journal of Geological Sciences. 3 (2): 187-193.

[3]. Lee, J.-Y., Marti, K., Severinghaus, J.P., Kawamura, K., Yoo, H.-S., Lee, J.B., Kim, J.S., A, (2006): Redetermination of the Isotopic Abundances of Atmospheric Ar, Geochimica et osmochimica Acta, V70, 4507-4512.

[4]. Macleod, W. N. Turner, D.C. and Wright, E. P. (1971): The Geology of Jos-Plateau, Vo.1 General Geology. Geol. Surv. Of Nigeria. Bull N0. 32.

[5]. McDougall, I. and T.M. Harrison, (1999): Geochronology and Thermo chronology by the ${ }^{40} \mathrm{Ar} /{ }^{39} \mathrm{Ar}$ Method: Oxford Monographs on Geology and Geophysics no. 9, Second Edition. Oxford University Press, New York, 269pp.

[6]. Renne, P.R., Mundil, R., Balco, G., Min, K. and Ludwig, K.R.,(2010): Joint Determination of ${ }^{40} \mathrm{~K}$ Decay Constants and 40Ar*/40K for the Fish Canyon Sanidine Standard, and Improved Turner, D. C., Macleod, W.N., Buchanan, M.S. (1971): The Geology of Jos Plateau. G.S.N. Bulletin 32, Vol.2, pp 107.

[7]. Wright, J. B. (1976): A Critical Review of the Geology of Nigeria .Edited by Kogbe, C.A. Elizabethan Publisher Company, Lagos, Nigeria. Pp 309-317.

[8]. Wright, J.B. (1989): Review of the Origin and Evolution of the Benue Trough in Nigeria. In: Geology of Nigeria (Edited By Kogbe, C,A,) Rock View (Nig.) Ltd., Jos 